\begin{tabular}{|c|l|}
\hline Title & $\begin{array}{l}\text { The roles of pyrite and calcite in the mobilization of arsenic and lead from hydrothermally altered rocks excavated in } \\
\text { Hokkaido, Japan }\end{array}$ \\
\hline Author(s) & Tabelin, Carlito Baltazar; Igarashi, Toshifumi; Tamoto, Shuichi; Takahashi, Ryohei \\
\hline Citation & $\begin{array}{l}\text { Journal of Geochemical Exploration, 119-120, 17-31 } \\
\text { https:/doi.org/10.1016/.gexplo.2012.06.003 }\end{array}$ \\
\hline Issue Date & 2012-08 \\
\hline Doc URL & http://hdl.handle.net/2115/51032 \\
\hline Type & article(author version) \\
\hline File Information & JGE119-120_17-31.pdf \\
\hline
\end{tabular}

Instructions for use 


\title{
The roles of pyrite and calcite in the mobilization of arsenic and lead from hydrothermally altered rocks excavated in Hokkaido, Japan
}

\author{
Carlito Baltazar Tabelin*1, Toshifumi Igarashi ${ }^{1}$, Shuichi Tamoto ${ }^{2}$ and Ryohei Takahashi ${ }^{3}$ \\ ${ }^{1}$ Laboratory of Groundwater and Mass Transport, Graduate School of Engineering, Hokkaido University, Sapporo 060- \\ 8628, JAPAN \\ ${ }^{2}$ Civil Engineering Research Institute for Cold Region, Public Works Research Institute, Sapporo 062-8608, JAPAN \\ ${ }^{3}$ Department of Earth Science and Technology, Graduate School of Engineering and Resource Science, Akita \\ University, Akita 010-8502, JAPAN \\ E-mails: carlito@trans-er.eng.hokudai.ac.jp, tosifumi@eng.hokudai.ac.jp, 95353@ceri.go.jp and ryohei@gipc.akita- \\ u.ac.jp
}

\begin{abstract}
This paper describes the enrichment of hydrothermally altered volcanic and sedimentary rocks with arsenic (As) and lead $(\mathrm{Pb})$, and the effects of pyrite and calcite on the mobilities and release mechanisms of these toxic elements under oxic and anoxic conditions. Enrichment of the altered rock with $\mathrm{As}$ and $\mathrm{Pb}$ predominantly occurred in precipitated pyrite grains and not on the alumino-silicate minerals making up the matrix of the rock. Arsenic was incorporated in pyrite grains formed during alteration in both volcanic and sedimentary rocks, but $\mathrm{Pb}$ was only found in the pyrite grains of the volcanic rock samples. When in contact with water, altered volcanic rocks had acidic $\mathrm{pH}$ while altered sedimentary rocks had alkaline $\mathrm{pH}$. The mobilities of both $\mathrm{As}$ and $\mathrm{Pb}$ from the altered rocks were enhanced at acidic and alkaline $\mathrm{pH}$ and a minimum was observed in the circumneutral $\mathrm{pH}$ under both oxic and anoxic conditions. The absence of $\mathrm{O}_{2}$ retarded the oxidation of pyrite most notably in the alkaline region but not in the acidic and circumneutral $\mathrm{pH}$. The absence of $\mathrm{CO}_{2}$ increased the $\mathrm{pH}$ of samples with significant calcite content but did not affect those containing substantial amounts of pyrite. Increasing the $\mathrm{CO}_{2}$ also had insignificant effect on the concentrations of $\mathrm{As}$ and $\mathrm{Pb}$ in the leachate. The mechanisms controlling the mobilization of $\mathrm{As}$ and $\mathrm{Pb}$ from these rocks like dissolution of soluble secondary minerals, pyrite oxidation and adsorption were all related to pyrite while the $\mathrm{pH}$ of the rock when in contact with water was controlled by pyrite and calcite. Thus, excavated waste rocks that have been altered can be grouped based on the relative abundance of pyrite and calcite and their $\mathrm{pH}$ when in contact with water.
\end{abstract}

Keywords: Pyrite; calcite; hydrothermal alteration; arsenic; lead; leaching

*Corresponding author: Tel: +81-11-706-6311 Fax: +81-11-706-6308

email: carlito@trans-er.eng.hokudai.ac.jp 


\section{Introduction}

Arsenic (As) and lead (Pb) are elements well known for their toxicity when ingested, inhaled or absorbed through the skin. Arsenic-contaminated groundwater used for drinking and cooking is the cause of health problems such as keratosis and cancers reported in Bangladesh and the West Bengal area of India (Acharyya et al., 2000; Akai et al., 2004; Burgess et al., 2010; Das et al., 1996; Dowling et al., 2002; Nickson et al., 2000). Although the source of contamination is believed to be natural, cases elsewhere such as those reported in Thailand, Ghana and some areas of the United States were due to the improper disposal of contaminated soil or rock from mining activities (Bowell, 1993; Choprapawon and Rodcline, 1997; Welch et al., 1999; Williams, 1997). Lead contaminations of soils have also been reported mostly from firing ranges and mining areas (Dermatas et al., 2006; Rabinowitz, 2005). Chronic Pb poisoning causes paralysis of the peripheral motor nerves, anemia, kidney damage, abnormal fetal development, and abnormal neurological development and function (Hammond, 1977; Moore and Goldberg, 1985; Sengupta, 2002). Because of this, extensive studies have been made to understand the sources, speciation, mobilization and remediation of these toxic elements especially in soils and groundwater (Brannon and Patrick, 1987; Lowers et al., 2007; Moore et al., 1988; O’Day et al., 2004; Peters and Blum, 2003; Savage et al., 2000; Smedley and Kinniburgh, 2002).

Among the known sources of As and $\mathrm{Pb}$, hydrothermally altered rocks are important especially in active volcanic regions like Japan. These rocks are enriched with metals like $\mathrm{Pb}$, chromium $(\mathrm{Cr})$, copper $(\mathrm{Cu})$, gold $(\mathrm{Au})$ and silver $(\mathrm{Ag})$ due to the action of hydrothermal solutions/fluids. Hydrothermal solutions/fluids containing solutes derived from magmatic water or from the wall rock migrate upward and the changes in equilibrium with space and time allow the deposition of these solutes (Pirajno, 2009). Hydrothermally altered rocks have been extensively studied 
especially in the context of ore formation, metal enrichment, and mineralization (Aiuppa et al., 2006; Allen and Hahn, 1994; Franzson et al., 2008; Halbach et al., 1993; Horton et al., 2001;

Huston et al., 1995; Marques et al., 2010; Martin-Crespo et al., 2004; Ostwald and England, 1977; Pokrovski et al., 2007), but very few have investigated the potential leaching of toxic elements from these rocks when exposed to the environment.

We have been studying in detail the mobilities of $\mathrm{As}$ and $\mathrm{Pb}$ from these high-volume and lowcontent sources with the primary goal of developing an alternative method for their disposal. Special landfills are currently used, but this is very expensive and unsustainable due to the large volume of rocks excavated that other methods should be explored. One of the biggest challenges encountered in the design of an alternative disposal method is to establish a simple but robust classification scheme for these excavated altered rocks. This is of primary importance because of their complex properties and large spatial variations in chemistry and mineralogy caused by hydrothermal alteration. The number of potentially toxic elements in these rocks is also variable, that is, other harmful elements like chromium (Cr), selenium (Se) and boron (B) are also found together with $\mathrm{As}$ and $\mathrm{Pb}$ in some excavated rocks. Moreover, the leaching behaviors of these toxic elements differ from each other even under the same geochemical conditions so that classifying these rocks based on their properties and leaching behaviors would maximize the efficiency of countermeasures incorporated in the design of the new disposal method. Developing this scheme requires the evaluation of processes involved in the enrichment of the altered rocks with respect to the toxic elements and the mechanisms controlling their mobilization from different kinds of altered rocks. Our previous papers showed that the mechanisms controlling the release of $\mathrm{As}$ and $\mathrm{Pb}$ from altered rocks were largely dependent on the $\mathrm{pH}$ and oxidation-reduction potential (Eh) similar to 
their observed behaviors in contaminated soils and groundwater (Igarashi et al, 2008; Tabelin and Igarashi, 2009; Tabelin et al., 2010; Tabelin et al., 2012a).

The samples used in our previous paper (Tabelin and Igarashi, 2009) were all taken from borehole cores of a single tunnel project. In contrast, the samples used in this study were collected not only from borehole cores but also from the bulk excavated rocks of several tunnel projects. Moreover, our previous publications did not address the following issues: the important minerals incorporating $\mathrm{As}$ and $\mathrm{Pb}$ in altered rocks, comparison of the leaching behavior and release mechanisms of borehole core and bulk excavated rock samples under oxic conditions, the leaching behavior and release mechanisms of $\mathrm{As}$ and $\mathrm{Pb}$ under anoxic conditions in the entire $\mathrm{pH}$ range, the individual effects of $\mathrm{O}_{2}$ and $\mathrm{CO}_{2}$ on $\mathrm{As}$ and $\mathrm{Pb}$ leaching, and the influence of minor minerals like pyrite and calcite on the mobilization of these toxic elements from altered rocks. All of these issues were elucidated in this study and the collected data were used to develop a classification scheme to group excavated rocks based on their chemical and mineralogical properties as well as the dominant release mechanisms of $\mathrm{As}$ and $\mathrm{Pb}$.

\section{Materials and methods}

\subsection{Materials}

Hydrothermally altered volcanic and sedimentary rock samples used in this study were obtained from tunnel projects around the island of Hokkaido, Japan. Altered andesite and tuff were collected from a former gold mine with epithermal gold-silver-copper deposit (location: Teine, Sapporo City) (Tabelin and Igarashi, 2009; Tatsuhara et al., 2012) while the altered sedimentary rock samples were obtained from two different tunnel projects for roads: one was mainly slate hosting silicified veins located in the town of Kamikawa (Tabelin et al., 2012a) and the other was composed of mudstone and sandstone with mild alteration from the town of Honbetsu near Obihiro City (Tabelin 
et al., 2012b). Details of the tunnel projects and a brief geological history of the samples are summarized in Table 1. Borehole core samples were collected by diamond core drilling prior to the blasting of the tunnel while bulk excavated rocks were sampled from interim storage sites that had been exposed to the atmosphere for ca. 6 months. Samples collected from the bulk excavated rock were air dried, coarsely crushed and sieved while those from the borehole cores were directly crushed and sieved $(<2 \mathrm{~mm})$. Samples taken from the $<2 \mathrm{~mm}$ fraction were further ground to $<50$ $\mu \mathrm{m}$ in preparation for the chemical and mineralogical analyses. Polished thin sections of the rock samples were also prepared for the microscopic, SEM-EDS and EPMA analyses.

\subsection{Chemical and mineralogical analyses of the rock samples}

The bulk chemical composition and mineral constituents of the rock samples were determined using X-ray fluorescence spectrometry (SPECTRO XEPOS, Rigaku Corporation, Japan) and X-ray diffraction spectrometry (MULTIFLEX, Rigaku Corporation, Japan), respectively. Both analyses were done using pressed powders of the sample. Loss on ignition (LOI) was measured by heating the samples $(<2 \mathrm{~mm})$ inside a furnace for 1 hour at $750^{\circ} \mathrm{C}$ after oven drying at $110^{\circ} \mathrm{C}$ for 24 hours.

Light and electron microscopes were used to examine the properties of pyrite crystals found in the altered rocks. Polarized and reflected light microscopes (open and crossed Nicols) were used to analyze the kind of alteration that had affected the rocks. A scanning electron microscope (SEM) was further used to investigate the crystal morphology of pyrite grains found in the rock. The SEM also has energy dispersive X-ray fluorescence spectrometry (EDS) capabilities and was used to take elemental maps of rock surfaces (SSX-550, Shimadzu Corporation, Japan). The SEM was operated using a $30.0 \mathrm{kV}$ accelerating voltage while the EDS maps were taken at 13,000 cps with $1000 \mathrm{~ms}$ time constant. An electron probe micro analyzer (EPMA) (JEOL Corporation, Japan) was utilized 
to measure the relative abundance of $\mathrm{As}$ and $\mathrm{Pb}$ in pyrite. All EPMA analyses were conducted using a $2.0 \times 10^{-8} \mathrm{~A}, 15 \mathrm{kV}$ primary electron beam and ZAF correction was utilized for the quantification of trace elements. Iron $(\mathrm{Fe})$, sulfur $(\mathrm{S})$, As and $\mathrm{Pb}$ concentrations were quantified using peak counting times of $20 \mathrm{~s}$ for $\mathrm{Fe}$ and $\mathrm{S}$, and $30 \mathrm{~s}$ for $\mathrm{As}$ and $\mathrm{Pb}$. Background counting times of $5 \mathrm{~s}$ were used for Fe and $\mathrm{S}$ while background counting times of $10 \mathrm{~s}$ were used for $\mathrm{As}$ and $\mathrm{Pb}$. L $\alpha$ X-ray lines were analyzed for $\mathrm{As}, \mathrm{K} \alpha \mathrm{X}$-ray lines for $\mathrm{Fe}$ and $\mathrm{S}$, and $\mathrm{M} \alpha \mathrm{X}$-ray lines for $\mathrm{Pb}$. The detection limit of the EPMA using the above conditions is $100 \mathrm{ppm}(0.01 \mathrm{wt} \%)$.

\subsection{Batch leaching experiments}

Batch leaching experiments were conducted under oxic (i.e., ambient) and anoxic (i.e., inside a glove box) conditions by mixing 15 grams of sample $(<2 \mathrm{~mm})$ and $150 \mathrm{ml}$ of prepared leachants. Hydrochloric acid $(\mathrm{HCl})$ and sodium hydroxide $(\mathrm{NaOH})$ solutions of varying concentrations were used as leachants. Deionized water $(18 \mathrm{M} \Omega \cdot \mathrm{cm})$ used in the preparation of the leachants was obtained from a Millipore Milli-Rx 12 $\alpha$ system (Millipore Corporation, USA). Triplicate leaching experiments were done for samples SR1 and VR4 under oxic conditions using deionized water as leachant to estimate deviations of the leachate chemistry due to the heterogeneity of the crushed rock samples. Two kinds of anoxic experiments were conducted: one was under pure argon (Ar) gas and the other under mixed $\mathrm{CO}_{2}$ and $\mathrm{Ar}$ gases. In the anoxic experiments under pure $\mathrm{Ar}$ gas, the $\mathrm{pH}$ of the leachants was adjusted using reagent grade $\mathrm{NaOH}$ or $\mathrm{HCl}$ solution. On the other hand, only deionized water was used as leachant under mixed $\mathrm{CO}_{2}$ and $\mathrm{Ar}$ gases (i.e., 1, 3 or $30 \%$ of $\mathrm{CO}_{2}$ gas with Ar gas as the remainder). To ensure that truly anoxic conditions exist in these experiments, leachant solutions were left in the glove box for ca. 10 minutes while the vacuum pump was still running. This resulted in the "boiling" of the solution and expulsion of dissolved gases. Also, dissolved $\mathrm{O}_{2}$ (DO) was monitored prior to the anoxic experiments using an oxygen probe (Water 
checker IWC-5, Sansyo Corporation, Taiwan) and were always 0\% DO. Anoxic leaching experiments were conducted under different gas compositions to identify the individual effects of $\mathrm{O}_{2}$ and $\mathrm{CO}_{2}$ on the mobilities of $\mathrm{As}$ and $\mathrm{Pb}$ from the rock. In all of the leaching experiments, mixing was done at $120 \mathrm{rpm}$ using a reciprocal shaker. The $\mathrm{pH}$ and Eh of the suspensions were measured after 24 hours followed by filtration through $0.45 \mu \mathrm{m}$ Millex ${ }^{\circledR}$ sterile membrane filters (Millipore Corporation, USA). Filtrates collected were then analyzed for their toxic and major elements concentrations. The mixing time was fixed at 24 hours based on the study of Igarashi et al. (2008), which showed that apparent equilibrium was reached after 1 day of leaching for hydrothermally altered crushed rocks.

\subsection{Chemical analysis of the leachate}

The chemical analysis of the leachates was carried out using an inductively coupled plasma atomic emission spectrometer (ICP-AES) (ICPE-9000, Shimadzu Corporation, Japan). Arsenic concentrations less than $0.1 \mathrm{mg} / \mathrm{L}$ were analyzed using the hydride generation process coupled with the ICP-AES. In preparation for the hydride generation analysis, $30 \mathrm{ml}$ of leachate was mixed with $15 \mathrm{ml}$ of $12 \mathrm{M} \mathrm{HCl}, 2 \mathrm{ml}$ of $20 \%$ potassium iodide (KI) solution, $1 \mathrm{ml}$ of $10 \%$ ascorbic acid solution and diluted with deionized water to $50 \mathrm{ml}$. All chemicals used in the preparation and analysis were reagent grade. Lead concentrations less than $0.1 \mathrm{mg} / \mathrm{L}$ were analyzed using an ultrasonic aerosol generator connected to the ICP-AES. The concentrations of other coexisting ions (e.g., $\mathrm{Ca}^{2+}$ and $\mathrm{Fe}$ ) were also analyzed using ICP-AES including $\mathrm{SO}_{4}{ }^{2-}$, which was the major species of $\mathrm{S}$ found in the leachate using anion chromatography (ICS - 90, Dionex Corporation, USA). The standard ICPAES method (i.e., without attachment) has a margin of error of ca. $2-3 \%$ while the more sensitive hydride generation process and ultrasonic aerosol generator have uncertainties of ca. $5 \%$. The detection limits of the standard ICP-AES method for $\mathrm{Ca}, \mathrm{Fe}, \mathrm{S}, \mathrm{Pb}, \mathrm{As}, \mathrm{Al}$ and $\mathrm{Si}$ are approximately 
$0.1,2,0.02,9,40,20$ and $4 \mu \mathrm{g} / \mathrm{L}$, respectively. The hydride generation method for As has a detection limit of $0.1 \mu \mathrm{g} / \mathrm{L}$ while the ultrasonic aerosol generator attachment has a detection limit of $1 \mu \mathrm{g} / \mathrm{L}$.

\subsection{Geochemical modeling}

Thermodynamic calculations using geochemical models in conjunction with our experimental results could provide additional insights into the processes occurring in a rock-water-air system under equilibrium conditions. PHREEQC (Parkhurst and Apello, 1998) was used to calculate the saturation indices of several minerals important in the mobilization of $\mathrm{As}$ and $\mathrm{Pb}$ like $\mathrm{Fe}$ and $\mathrm{Al}-$ oxyhydroxides/oxides, carbonates and sulfates. It was also used to simulate ideal systems composed of one or more of the following minerals: calcite $\left(\mathrm{CaCO}_{3}\right)$, pyrite $\left(\mathrm{FeS}_{2}\right)$, gypsum $\left(\mathrm{CaSO}_{4} \cdot 2 \mathrm{H}_{2} \mathrm{O}\right)$ and melanterite $\left(\mathrm{FeSO}_{4} \cdot 7 \mathrm{H}_{2} \mathrm{O}\right)$. In these simulations, the amounts of calcite and/or pyrite were assumed from their relative abundance in the rock (XRD results). For example, when calcite is present as a minor mineral and pyrite as a trace mineral the assumed amounts are 10 and $1 \mathrm{~mol}$, respectively. Gypsum and melanterite were selected as representative soluble $\mathrm{Ca}$ and $\mathrm{Fe}$-sulfates, respectively. In addition, PHREEQC was also used to simulate the effects of $\mathrm{O}_{2}$ and $\mathrm{CO}_{2}$ on the leachate chemistry of an ideal system of calcite-pyrite-soluble $\mathrm{Ca}$ and Fe-sulfates. Moreover, the RXN program of the Geochemist's workbench ${ }^{\circledR}($ Bethke, 1992) was used to evaluate changes in the precipitation of Fe-oxyhydroxides and oxides with or without $\mathrm{O}_{2}$. Precipitation reactions without $\mathrm{O}_{2}$ were calculated using $\mathrm{N}_{2}$ in place of Ar because the aforementioned geochemical model did not include Ar gas used in this study.

\section{Results}

\subsection{Sample Characterization}


The bulk chemical compositions of the altered rock samples are summarized in Table 2. This table shows that altered andesite and tuff from the Teine deposit have S contents greater than $1 \mathrm{wt} \%$ and As contents greater than $100 \mathrm{ppm}$, which is ca. 100 times higher than the average As content of igneous rocks (average As content of igneous rocks is ca. $1.5 \mathrm{ppm}$ (Ure and Berrow, 1982)). In the altered sedimentary rocks, S and As contents are less than $0.5 \mathrm{wt} \%$ and $24 \mathrm{ppm}$, respectively and are significantly lower than those found in the altered volcanic rocks. Lead content is also high in the altered volcanic rock samples (>100 ppm), but was not detected in the altered sedimentary rock samples. Although both kinds of altered rocks are predominantly composed of silicate minerals (i.e., quartz and/or feldspar), the altered volcanic rock samples contain pyrite as a minor mineral while the altered sedimentary rock samples have calcite as a minor mineral (Table 3). Galena (PbS) was only detected as a trace mineral in one of the altered volcanic rock samples (VR3).

\subsection{Hydrothermal alteration of the sedimentary and volcanic rocks}

Fractures running through the rock (sample SR3) and the changes that happened on the rock grains located along these fractures are clearly visible in Figure 1. Also, this figure shows pyrites formed inside and outside the fractured zone. Pyrite grains located outside the fractured zone were formed inside the calcified remains of a marine protozoan known as foraminifer (Figure 2). The crystals inside the calcareous protozoan shell are botryoidal (i.e., globular external form resembling a bunch of grapes) with surfaces bounded by the foraminifer shell. On the other hand, smectite and illite are observed inside the fractured zone together with pyrite as illustrated in Figure 3. The morphology of pyrite located in the fractured area is framboidal with its distinct spherical equi-granular micro crystals of ca. $2 \mu \mathrm{m}$ diameter that are closely packed together (Figure 3(b)). Our EPMA results show that this framboidal pyrite has incorporated As amounting to as much as $0.13 \mathrm{wt} \%(1,300$ ppm) while those formed inside the foraminifer shell did not have measurable amounts of As in the 
crystal (Table 4). The amounts of $\mathrm{Pb}$ in pyrite grains formed inside and outside the fractured zone were all less than the detection limit of the EPMA (Table 4). Also, illite and smectite surrounding the pyrite grains inside the fractured area have measurable amounts of $\mathrm{As}$ and $\mathrm{Pb}$ (Table 4).

Evidences of alteration were also observed in the altered volcanic rock samples as illustrated in Figure 4(a). Several altered plagioclase grains are visible together with alteration products like illite and pyrite. Pyrite crystals found in the altered volcanic rock samples have angles characteristic of hexagonal, cubic, or pyritohedron morphologies, but their complete shapes were not visible because the samples used were polished sections (Figure 4(b)). The SEM-EDS maps of one of these crystals (Figure 5) indicate that As is preferentially distributed into pyrite and not with the surrounding alumino-silicate minerals. It was also observed that the relative abundance of As in pyrite was higher around growth areas (Figure 5(c)). In Figure 5, the pictured pyrite grain is located on "top" of the alumino-silicate minerals, therefore the silicon $(\mathrm{Si})$ and aluminum $(\mathrm{Al})$ present inside the pyrite grain is probably a result of over-polishing and not an integral part of the pyrite crystal. The relative abundance of $\mathrm{As}$ and $\mathrm{Pb}$ in pyrite found in the altered volcanic rock are summarized in Table 5. The average As content of pyrite found in these rock samples is 2,800 ppm with an observed range of $<100 \mathrm{ppm}$ to over $10,000 \mathrm{ppm}$. On the other hand, the average $\mathrm{Pb}$ content is $1,300 \mathrm{ppm}$ with a range of $<100$ to $2,600 \mathrm{ppm}$. Statistical analysis (F- and T-tests) showed that there were insignificant differences in the As content of pyrites found in altered volcanic and sedimentary rocks. Similarly, statistically significant differences in the As content of pyrites from VR1, VR2 and VR3 were not observed. In terms of the $\mathrm{Pb}$ content of pyrites, there were no statistical differences between the various volcanic rocks used in this study. Unfortunately, a similar statistical comparison of the $\mathrm{Pb}$ content of pyrites depending on rock type could not be made because of the 
very low $\mathrm{Pb}$ content of pyrites found in altered sedimentary rock (Note: Details of the statistical analysis are provided as supplementary tables).

\subsection{Effects of $\mathrm{O}_{2}$ and $\mathrm{CO}_{2}$ on arsenic and lead leaching}

Triplicate leaching experiments of samples SR1 (altered sedimentary rock) and VR4 (altered volcanic rock) show that the standard deviations in $\mathrm{pH}$ values and concentrations of $\mathrm{As}, \mathrm{Ca}^{2+}, \mathrm{SO}_{4}{ }^{2-}$ and Fe were all very low (Tables 6 and 7), which indicate that experimental errors associated with the heterogeneity of the altered rocks were negligible and the samples were properly and adequately homogenized. The leachate chemistry of the altered rock samples without $\mathrm{pH}$ adjustment is summarized in Table 8. Altered rocks containing pyrite as a minor mineral (all of the altered volcanic rock samples) had acidic leachate $\mathrm{pH}$ while those with calcite as a minor mineral (all of the altered sedimentary rocks) had alkaline $\mathrm{pH}$. The concentrations of As in the leachate of altered volcanic rock samples were higher $(45.4-195 \mu \mathrm{g} / \mathrm{L})$ than those from the altered sedimentary rocks $(17.3-28.3 \mu \mathrm{g} / \mathrm{L})$. The altered volcanic rocks also leached out $\mathrm{Pb}$ amounting to as much as 2.12 $\mathrm{mg} / \mathrm{L}$. In the altered volcanic rocks, the leachate of the sample taken from the bulk waste (VR4) had lower $\mathrm{pH}$ and significantly higher concentrations of $\mathrm{Fe}$ and $\mathrm{SO}_{4}{ }^{2-}$ than the borehole core samples (VR1, VR2 and VR3). A similar trend was also observed in the leachate concentrations of Fe and $\mathrm{SO}_{4}{ }^{2-}$ from borehole core (SR 2) and bulk (SR 1) samples of the altered sedimentary rock.

Table 9 illustrates the changes in the leachate chemistry of the altered volcanic rock as a function of gas composition. The $\mathrm{pH}$ of the leachate did not change dramatically with or without $\mathrm{O}_{2}$ and $\mathrm{CO}_{2}$, but the mobilization of As was enhanced from ca. $12 \mu \mathrm{g} / \mathrm{L}$ without $\mathrm{O}_{2}$ to $102 \mu \mathrm{g} / \mathrm{L}$ with $\mathrm{O}_{2}$. This eight-fold increase in As concentration was accompanied by significant increases in the Fe and $\mathrm{SO}_{4}{ }^{2-}$ concentrations in the leachate (Table 7). In contrast, significant variations in $\mathrm{Pb}$ 
concentrations with changing $\mathrm{O}_{2}$ and $\mathrm{CO}_{2}$ compositions were not observed in the leachate of the altered volcanic rock. The leachate $\mathrm{pH}$ of altered sedimentary rock samples containing calcite was dependent on $\mathrm{CO}_{2}$ as illustrated in Table 10. Increasing the amount of $\mathrm{CO}_{2}$ from 0 to $30 \%$ dramatically decreased the $\mathrm{pH}$ from 9.2 to 6.1 accompanied by a significant increase in $\mathrm{Ca}^{2+}$ concentration. However, the highest concentration of As in the leachate was observed under oxic conditions when both $\mathrm{O}_{2}$ and $\mathrm{CO}_{2}$ are present and not at higher $\mathrm{CO}_{2}$ values.

\subsection{Effects of pH on arsenic and lead leaching under oxic conditions}

The leaching behavior of As in altered volcanic and sedimentary rocks across the entire $\mathrm{pH}$ range under oxic conditions is illustrated in Figure 6. The results show similar leaching behaviors in both altered rocks, that is, more As were released under alkaline and acidic conditions with minimum in the circumneutral $\mathrm{pH}$ range $(6-8)$ and were consistent with our earlier published works (Tabelin and Igarashi, 2009; Tabelin et al., 2010). With pH variation, leachates from the borehole core samples of the altered volcanic rock (VR1, VR2 and VR3) had higher concentrations of As than the bulk excavated rock samples (VR4) especially around the acidic and alkaline $\mathrm{pH}$ range (Figure 6(a)). In contrast, As concentrations in leachates from borehole core of the altered sedimentary rock (SR2) were lower than those collected from the bulk rock (SR1) in the acidic and alkaline pH range (Figure 6(b)). In the acidic region, concentrations of As in the leachates of altered volcanic and sedimentary rock samples were found around a similar range of values (altered sedimentary rocks: $60-400 \mu \mathrm{g} / \mathrm{L}$; altered volcanic rocks: $100-700 \mu \mathrm{g} / \mathrm{L})$. Strong positive ( $>0.90)$ and statistically significant $(\mathrm{p}<0.05)$ correlations in the concentrations of $\mathrm{Ca}^{2+}, \mathrm{Fe}$ and $\mathrm{As}$ in both types of altered rocks were also observed under these conditions. In the alkaline region, concentrations of As in the leachates of the altered volcanic rocks were in the range of ca. $500-3000 \mu \mathrm{g} / \mathrm{L}$, which were more than 20 times higher in comparison to those observed in the altered sedimentary rock samples 
(range: $20-150 \mu \mathrm{g} / \mathrm{L}$ ). The $\mathrm{SO}_{4}{ }^{2-}$ curves of the altered volcanic rock increased with increasing $\mathrm{pH}$ similar to that of pure pyrite while those of the sedimentary rock samples decreased with $\mathrm{pH}$

(Figure 7). Moreover, $\mathrm{SO}_{4}{ }^{2-}$ concentrations in the leachate of altered volcanic rocks were more than 10 times higher than those from the altered sedimentary rocks.

Figure 8 illustrates that the leaching behavior of $\mathrm{Pb}$ is also enhanced in the acidic and alkaline $\mathrm{pH}$ regions with minimum at the circumneutral $\mathrm{pH}$ range. However, the amount of $\mathrm{Pb}$ leached out appears to be more significant in the acidic than the alkaline region since as much as $2.39 \mathrm{mg} / \mathrm{L}$ of $\mathrm{Pb}$ was released at $\mathrm{pH}$ 2.6. Although the amount of $\mathrm{Pb}$ in the alkaline region was lower, it still amounted to $0.23 \mathrm{mg} / \mathrm{L}$ at $\mathrm{pH} 12$. Also, $\mathrm{Pb}$ concentrations of leachates from the bulk rock were higher in the acidic region and slightly lower in the alkaline region than those from the borehole core samples. Similar to As, strong positive correlations $(\mathrm{R}>0.94)$ that were statistically significant $(\mathrm{p}<0.025)$ also existed between $\mathrm{Ca}^{2+}, \mathrm{Fe}$ and $\mathrm{Pb}$ in the acidic region. Unfortunately, only altered volcanic rocks have significant concentrations of $\mathrm{Pb}$ so that a comparison of its leaching behavior depending on the type of rock could not be made.

\subsection{Effects of pH on arsenic and lead leaching under anoxic conditions}

Figure 9(a) illustrates the leaching behavior of As under anoxic conditions throughout the entire $\mathrm{pH}$ range from the altered volcanic rock samples. The leaching behavior of As from these rocks was similar with or without $\mathrm{O}_{2}$ and $\mathrm{CO}_{2}$, that is, As leaching was enhanced in both acidic and alkaline $\mathrm{pH}$ regions. Anoxic conditions clearly reduced the mobilization of As in the alkaline region, but had minimal effect in the acidic and circumneutral $\mathrm{pH}$ regions. Similarly, the mobilization of $\mathrm{Pb}$ was $\mathrm{pH}$ dependent even under anoxic conditions as shown in Figure 9(b). The amount of Pb released from the rock samples also decreased in the alkaline region under anoxic conditions similar to that of As. 
At $\mathrm{pH}$ less than 4, the concentrations of $\mathrm{Pb}$ under oxic and anoxic conditions were identical. However, between $\mathrm{pH} 4-6$, the concentration of $\mathrm{Pb}$ in the leachate was conspicuously higher under anoxic condition. In this $\mathrm{pH}$ region, Fe concentrations were also significantly higher under anoxic than oxic conditions, which is identical to those observed with Pb (Figure 10(a)).

Concentrations of $\mathrm{SO}_{4}{ }^{2-}$ in the leachate also decreased dramatically under alkaline conditions in the absence of $\mathrm{O}_{2}$, but were similar under circumneutral and acidic $\mathrm{pH}$ (Figure 10(b)). Moreover, the decrease of $\mathrm{As}$ and $\mathrm{Pb}$ concentrations in the alkaline region under anoxic conditions occurred in conjunction with the decrease in $\mathrm{SO}_{4}{ }^{2-}$ concentrations of the leachate.

The leaching behavior of As from altered sedimentary rocks under anoxic condition had the same U-shaped curve observed under oxic conditions as illustrated in Figure 11. However, there are three distinct regions in these curves where the concentrations of As changed significantly in the absence of $\mathrm{O}_{2}$ and $\mathrm{CO}_{2}$. Region $1(\mathrm{R} 1)$ is located in the acidic region at $\mathrm{pH}$ less than 4 , region 2 (R2) is found in between $\mathrm{pH} 4-8$ and region $3(\mathrm{R} 3)$ is in the alkaline region at $\mathrm{pH}$ greater than 8 . In R1 and R3, the amount of As released from the altered sedimentary rock decreased under anoxic conditions while in R2, the concentration of As in the leachate increased. The effect of anoxic conditions on the concentration of Fe was only observed at $\mathrm{pH}<4$ (Figure 12(a)). At higher $\mathrm{pH}$ values, low concentrations of Fe in the leachate made the differentiation difficult. Significant changes in the concentrations of $\mathrm{Ca}^{2+}$ and $\mathrm{SO}_{4}{ }^{2-}$ were also observed as illustrated in Figures 12(b) and (c). Under anoxic conditions, the concentrations of $\mathrm{Ca}^{2+}$ at $\mathrm{pH}<4$ decreased but not at $\mathrm{pH}>4$. For $\mathrm{SO}_{4}{ }^{2-}$, anoxic conditions increased its concentration in the leachate at $\mathrm{pH}<8$ but decreased at $\mathrm{pH}>8$.

\subsection{Geochemical modeling}


Tables 11 and 12 show the saturation indices of $\mathrm{Pb}, \mathrm{Ca}$ and $\mathrm{Fe}$ minerals in the leachate of samples VR1 (altered volcanic rock) and SR1 (altered sedimentary rock), respectively. The pe values used in the modeling were calculated from the measured Eh of the leachates. In the altered volcanic rocks, precipitations of $\mathrm{Pb}$ minerals like $\mathrm{Pb}(\mathrm{OH})_{2}$ and hydrocerrusite $\left(\mathrm{Pb}\left(\mathrm{CO}_{3}\right)_{2}(\mathrm{OH})_{2}\right)$ are thermodynamically possible under alkaline conditions while Fe oxides/oxyhydroxides precipitates may form at $\mathrm{pH}>3$. Calcite is predicted to precipitate in the leachates of the altered sedimentary rock under alkaline conditions together with the oxides and oxyhydroxides of Fe. In both types of rocks, the stability of Fe-oxyhydroxides/oxides, calcite, and $\mathrm{Pb}(\mathrm{OH})_{2}$ decreases with increasing acidity. Furthermore, modeling results summarized in Table 13 show that the equilibrium constants $(K)$ of Fe-oxyhydroxides/oxides precipitation reactions with a more inert gas $\left(\mathrm{N}_{2}\right)$ are lower in comparison to similar reactions with $\mathrm{O}_{2}$, which indicates that the extent of Fe-oxyhydroxides/oxides precipitation is minimized under anoxic conditions.

Table 14 shows the $\mathrm{pH}$ and concentrations of $\mathrm{Ca}^{2+}, \mathrm{Fe}$ and $\mathrm{SO}_{4}{ }^{2-}$ in several simulated systems and those measured in sample SR1. Simulated $\mathrm{pH}$ and concentrations of $\mathrm{Ca}^{2+}$ and $\mathrm{SO}_{4}{ }^{2-}$ in the calcite-pyrite-gypsum-melanterite ideal system closely resembled those measured in sample SR1, which suggest that the $\mathrm{pH}$ of the altered rock-water system as well as the concentrations of $\mathrm{Ca}^{2+}$ and $\mathrm{SO}_{4}{ }^{2-}$ in the leachate could be adequately explained by these four mineral phases. Inclusion of pyrite in the calcite-only system decreased the $\mathrm{pH}$ by $0.6 \mathrm{pH}$ units. Similarly, addition of soluble $\mathrm{Ca}$ and Fe-sulfate minerals in the calcite-pyrite system further decreased the $\mathrm{pH}$ by ca. $0.4 \mathrm{pH}$ units. In total, addition of pyrite and soluble minerals into the calcite-only system resulted in a $\mathrm{pH}$ decrease of ca. $1 \mathrm{pH}$ unit. Contribution of calcite dissolution alone on the total concentration of $\mathrm{Ca}^{2+}$ is estimated at ca. $19 \%$. However, this value roughly doubled to ca. $37 \%$ after the introduction of pyrite probably due to the increased dissolution of calcite to neutralize the acidity produced by 
pyrite oxidation. Similarly, ca. $19 \%$ of the total $\mathrm{SO}_{4}{ }^{2-}$ concentration of the leachate could be attributed to pyrite oxidation. This means that majority of the $\mathrm{Ca}^{2+}(63 \%)$ and $\mathrm{SO}_{4}{ }^{2-}(81 \%)$ dissolved in the leachate originates from the dissolution of soluble $\mathrm{Ca}$ and $\mathrm{Fe}$ phases. Concentrations of Fe from the simulations were ca. 1 - 3 orders of magnitude higher than the experimental results, which could be attributed to the different chemical forms/species of Fe critical to its precipitation that were not included in the model.

For the altered volcanic rock, measured $\mathrm{Ca}^{2+}, \mathrm{Fe}$ and $\mathrm{SO}_{4}{ }^{2-}$ concentrations were successfully simulated using a pyrite-gypsum-melanterite system (Table 15). However, the simulated pH was ca. $1.2 \mathrm{pH}$ units higher than the measured values, which is probably due to sulfuric acid produced by the atmospheric/partial oxidation of pyrite in the rock that is neglected in the simulation. The contributions of pyrite oxidation and dissolution of soluble $\mathrm{Ca}$ and $\mathrm{Fe}$-sulfates to the total $\mathrm{SO}_{4}{ }^{2-}$ concentration of the leachate were estimated at around 2 and 98\%, respectively. Concentrations of $\mathrm{As}$ and $\mathrm{Pb}$ are not present in the simulated results because these elements are present in the rock mostly as impurities of pyrite rather than as distinct mineral phases. However, the individual contributions of pyrite, calcite and soluble phases to the leaching of $\mathrm{As}$ and $\mathrm{Pb}$ could be estimated from the simulated results of $\mathrm{Ca}^{2+}$ and $\mathrm{SO}_{4}{ }^{2-}$ because the release of $\mathrm{As}$ and $\mathrm{Pb}$ from the rock is associated with minerals like pyrite

Both $\mathrm{O}_{2}$ and $\mathrm{CO}_{2}$ have strong effects on an ideal calcite-pyrite-gypsum-melanterite system as shown in Table 16. The $\mathrm{pH}$ of the leachate tends to decrease as the simulated system approaches oxic conditions, which is similar to the trends of the measured results (sample SR1). Similar trends were also observed in the $\mathrm{Ca}^{2+}$ and $\mathrm{SO}_{4}{ }^{2-}$ concentration results of both simulation and experiment. These gases also strongly influenced the $\mathrm{pH}$ of an ideal pyrite-gypsum-melanterite system as shown in Table 17. The $\mathrm{pH}$ dramatically decreased from 6 under anoxic condition to 4 at oxic conditions. 
This trend was also observed in the measured results (sample VR4), but the magnitude of the decrease was substantially lower. In contrast, concentrations of $\mathrm{Ca}^{2+}$ and $\mathrm{SO}_{4}{ }^{2-}$ were not affected by $\mathrm{O}_{2}$ and $\mathrm{CO}_{2}$ in both the simulated and measured results.

\section{Discussion}

\subsection{Arsenic and lead in hydrothermally altered rocks}

The partly altered sedimentary rock sample in this study had both altered and unaltered zones with each zone containing pyrite grains. In the unaltered zone, the shell bounding the pyrite crystals was mostly composed of calcite and was located away from the fractured zone (Figures 1 and 2).

Because this shell was still intact and the minerals surrounding it were markedly different from those in the altered zone, pyrite grains inside the shell were most likely formed during the sedimentation process with pyrite probably replacing the foraminifer and not due to hydrothermal alteration. In contrast, alteration probably occurred around the fractured area resulting in the formation of pyrite, illite, and smectite. Sedimentary rocks usually have layered structures that will cause variations of their mineral composition. However, this layered structure was not apparent in Figure 1 as evidenced by the identical mineral grain sizes and composition above and below the fractured area. Furthermore, the presence of illite and smectite only around the fractured zone supports our deduction that the rock underwent hydrothermal alteration. Illite and smectite have been used by several authors as indicators of hydrothermal alteration. De Carlo et al. (1983) and Dekov et al. (2008) pointed out that smectite can directly precipitate from hydrothermal fluids especially under alkaline conditions with low $\mathrm{Si}$ activity and $\mathrm{Mg} / \mathrm{Al}$ ratio. On the other hand, illite can be an alteration product of smectite during hydrothermal annealing according to this sequence (Alt and Jiang, 1991; Kisch, 1983; Srodon and Eberl, 1984): 
Smectite $\longrightarrow$ random Illite/Smectite $\longrightarrow$ ordered Illite/Smectite $\longrightarrow$ Illite

This type of alteration where clay minerals (e.g., illite and smectite) replace plagioclase is termed argillic alteration. Argillic alteration is characterized by the formation of clay minerals due to intense $\mathrm{H}^{+}$metasomatism and acid or base leaching at temperatures between 100 and $300^{\circ} \mathrm{C}$ (Pirajno, 2009).

On the other hand, the volcanic rock samples most likely underwent phyllic/sericitic alteration that resulted in the formation of illite and pyrite in partly altered grains of plagioclase (Figure 4 (a)). Phyllic/sericitic alteration is one of the most common types of hydrothermal alteration and is essentially due to the destabilization of feldspars in the presence of $\mathrm{H}^{+}, \mathrm{OH}^{-}, \mathrm{K}$, and $\mathrm{S}$ to form quartz, illite and pyrite, and simultaneously leaching out $\mathrm{Na}, \mathrm{Mg}$, and $\mathrm{Fe}$ in the process (Pirajno, 2009). The original rock (i.e., the precursor rock) in Figure 4(a) is probably porphyritic based on the large plagioclase grains within the rock matrix.

The As content of pyrite formed under hydrothermal conditions was in the wt $\%$ values while those formed during sedimentation were surprisingly below the detection limit of the EPMA (Table 4). These results suggest that As-rich solutions like hydrothermal fluids when present during pyrite formation would facilitate As incorporation into pyrite. This interpretation is consistent with the reports of other authors who also emphasized the importance of an As-rich solution in the formation of arsenian pyrite in both hydrothermal systems and sedimentary deposits (Bostick and Fendorf, 2003; Kirk et al., 2004; Lowers et al., 2007; O’Day et al., 2004; Savage et al., 2000). Also, the relative abundance and variability of As incorporation into pyrite was higher than $\mathrm{Pb}$. Arsenic was measured in almost all of the pyrite grains regardless of rock type while $\mathrm{Pb}$ was only measured in pyrite crystals found in altered volcanic rocks (Tables 4 and 5). This relatively higher abundance of 
As in pyrite suggests that it is preferentially incorporated into pyrite in comparison to $\mathrm{Pb}$.

According to Huston et al. (1995), the incorporation of $\mathrm{Pb}$ into pyrite, like $\mathrm{Cu}$ and $\mathrm{Zn}$, is most likely through the inclusion of other sulfide minerals containing these elements (e.g., galena, chalcopyrite and sphalerite) and not directly into the crystal lattice. In contrast, As, with its smaller atomic size and similar properties to $\mathrm{S}$, could be incorporated directly into the pyrite lattice most probably as nonstoichiometric substitutions or as a metastable $\mathrm{Fe}(\mathrm{As}, \mathrm{S})_{2}$ solid solution (Fleet et al., 1989; Huston et al., 1995).

The altered volcanic and sedimentary rock samples used in this study underwent different types of alteration as discussed above, but the enrichment of the rock with As and $\mathrm{Pb}$ preferentially occurred in and around precipitated pyrite grains and not on the silicate and/or aluminate mineral matrix of the rock (Figure 5; Tables 4 and 5). These results suggest that pyrite is one of the primary sources of $\mathrm{As}$ and $\mathrm{Pb}$ in hydrothermally altered rocks regardless of the type of alteration, and this mineral would therefore strongly influence the mobilization of both elements when these rocks are exposed to the environment.

\subsection{Soluble arsenic and lead-bearing phases, calcite dissolution and pyrite oxidation}

Pyrite is one of the primary sources of $\mathrm{As}$ and $\mathrm{Pb}$ in hydrothermally altered rocks. However, altered rocks have complex chemical and mineralogical compositions, which mean that other constituent minerals could have significant effects on the mobilities of the toxic elements in these systems. Minerals of particular importance include those that have strong acid/base buffering capacities like calcite and pyrite because of the highly $\mathrm{pH}$-dependent leaching behavior of $\mathrm{As}$ and $\mathrm{Pb}$ from these rocks (Tabelin and Igarashi, 2009; Tabelin et al., 2010, Tabelin et al., 2012a). The altered volcanic and sedimentary rocks used in this study had acidic and alkaline $\mathrm{pH}$ values when in contact with 
water, respectively, which could be attributed to the relative abundance of pyrite and calcite in the rock samples (Tables 3, 6, 14 and 15). The acidic $\mathrm{pH}$ of leachates from the altered volcanic rock samples indicates that pyrite oxidation is dominant and these rocks have very low acid buffering capacities (Tables 6 and 15). Pyrite oxidation generates acidity according to the following reaction:

$$
\mathrm{FeS}_{2(\mathrm{~s})}+3.5 \mathrm{O}_{2(\mathrm{aq})}+\mathrm{H}_{2} \mathrm{O} \longrightarrow \mathrm{Fe}^{2+}+2 \mathrm{H}^{+}+2 \mathrm{SO}_{4}{ }^{2-} \quad \text { Equation } 1
$$

On the other hand, the alkaline $\mathrm{pH}$ characteristic of the altered sedimentary rock samples was mainly due to calcite. The $\mathrm{pH}$ of a system controlled by carbonate minerals, such as calcite, will depend on whether the rock-water system is "open" or "closed" with respect to atmospheric $\mathrm{CO}_{2}$. A system open to $\mathrm{CO}_{2}$ generally has a lower $\mathrm{pH}$ between 7.0 and 8.3 while a closed system has a higher $\mathrm{pH}$ usually in the range of 7.6 - 10.1 (Appelo and Postma, 2005). The alkaline leachate $\mathrm{pH}$ of the altered sedimentary rocks also indicates that the strong buffering effect of calcite was more than sufficient in neutralizing the acidity produced by the oxidation of pyrite (Tables 8 and 14).

It was observed that leachate of samples taken from the bulk excavated rock had higher concentrations of $\mathrm{Fe}$ and $\mathrm{SO}_{4}{ }^{2-}$ compared to those of the borehole cores (Table 6). The increase is particularly evident in the leachates of altered volcanic rocks where the concentrations of Fe and $\mathrm{SO}_{4}{ }^{2-}$ from the bulk excavated rock were more than ten times higher than those in the borehole cores. These could be attributed to the atmospheric/partial oxidation of the bulk rock during excavation, transport and storage prior to sampling, which induced the formation of more soluble secondary phases especially on the surfaces of exposed pyrite grains. Pyrite oxidation starts rapidly upon exposure to the atmosphere, commencing with the oxidation of $\mathrm{S}^{2-}$ species (Schaufuss et al., 1998). Oxidation is further enhanced in the presence of water or moisture that could strip reaction products on the pyrite surface exposing "fresh" sites for further oxidation. Atmospheric pyrite 
oxidation leads to the formation of Fe-sulfates, Fe oxyhydroxides/oxides, which are soluble especially under acidic conditions (De Donato et al., 1993; Schaufuss et al., 1998; Todd et al., 2003). Dissolution of these soluble products of atmospheric/partial oxidation of pyrite enhanced the mobility of $\mathrm{Pb}$ but not As (Table 8). These differences could be attributed to the strong adsorption of As onto Fe-oxyhydroxides/oxides, which were also formed as a consequence of pyrite oxidation (Cornelis et al., 2008; Dousova et al., 2003; Dzombak and Morel, 1990; Gosh and Teoh, 1985; Lin and Puls, 2000; Wang and Mulligan, 2006). In contrast, $\mathrm{Pb}$ precipitation or adsorption onto Feoxyhydroxides/oxides was minimal especially in the acidic region, which could explain its substantial increase in the leachate of the bulk rock (Tables 8 and 11). Regardless of these seemingly opposing trends, majority of the $\mathrm{As}$ and $\mathrm{Pb}$ leached out from both volcanic and sedimentary altered rocks were supplied by the dissolution of these soluble $\mathrm{Ca}$ and Fe-sulfates under conditions close to equilibrium and without $\mathrm{pH}$ adjustment (Tables 6, 14 and 15). However, it should be noted that the contribution of these soluble phases to the As and $\mathrm{Pb}$ load of the leachate would precipitously decrease with time especially when the leachant (i.e., water) is constantly renewed/transported (Tabelin et al., 2012a, b).

\subsection{Mechanisms controlling the mobilities of arsenic and lead under anoxic conditions}

Gaseous $\mathrm{O}_{2}$ and $\mathrm{CO}_{2}$ strongly influenced the $\mathrm{pH}$ of the altered rock-water system and can therefore affect the mobilities of $\mathrm{As}$ and $\mathrm{Pb}$. Increasing the $\mathrm{CO}_{2}$ decreased the leachate $\mathrm{pH}$ and increased the dissolution of calcite in altered sedimentary rocks, but did not have any significant effect on the concentration of As in the leachate (Tables 10,16 and 17). These results in conjunction with the low As content of calcite (Table 3) indicate that calcite found in the altered sedimentary rocks used in this study is not one of the primary sources of As. However, this might not be true for other hydrothermally altered rocks as noted by Horton et al. (2001). These authors reported that although 
most of the calcite samples that they analyzed had low As contents, those located in fault zones in direct contact with the hydrothermal fluid were rich in As (mean As content $=81.2 \mathrm{ppm}$ ). The absence of $\mathrm{O}_{2}$ significantly decreased the concentration of As in the leachate of the altered sedimentary rock even if the $\mathrm{pH}$ was higher. Similarly, the absence of $\mathrm{O}_{2}$ in the altered volcanic rock sample dramatically decreased the leaching of As without any dramatic changes on the $\mathrm{pH}$. These results were consistent with the $\mathrm{SO}_{4}{ }^{2-}$ concentration decrease without $\mathrm{O}_{2}$, which indicates that pyrite oxidation decreased in both types of rocks under anoxic conditions resulting in lower As concentrations in the leachate. These identical results observed in the two types of altered rocks suggest that pyrite oxidation and related oxidants $\left(e . g ., \mathrm{O}_{2}\right)$ are important in the mobilization of As from these sources (Tables 9 and 10).

Although $\mathrm{O}_{2}$ is an essential oxidant of pyrite as explained by Equation 1, the extent of its effect on pyrite oxidation was $\mathrm{pH}$ dependent (Figures 9 and 10). In the altered volcanic rock samples, removal of $\mathrm{O}_{2}$ had a significant effect on the amount of $\mathrm{SO}_{4}{ }^{2-}$ released especially in the alkaline region (Figure 10). This decrease in $\mathrm{SO}_{4}{ }^{2-}$ concentration under anoxic-alkaline conditions occurred together with that of As, which implies that the mobilization of As decreases under anoxic conditions because pyrite oxidation is minimized (Figure 10). In contrast, the effect of $\mathrm{O}_{2}$ on As and $\mathrm{SO}_{4}{ }^{2-}$ concentrations were minimal in the acidic and circumneutral $\mathrm{pH}$. These results have two important implications. First, the effects of $\mathrm{O}_{2}$ on pyrite oxidation under acidic and circumneutral $\mathrm{pH}$ is minimal. Second, a more powerful oxidant, probably $\mathrm{Fe}^{3+}$ ions, is available in these $\mathrm{pH}$ regions that overshadowed the effects of $\mathrm{O}_{2}$ on pyrite oxidation. Ferric ion $\left(\mathrm{Fe}^{3+}\right)$ and $\mathrm{O}_{2}$ are two of the most important oxidants of pyrite (Holmes and Crundwell, 2000; McKibben and Barnes, 1986; Moses et al., 1987; Moses and Herman, 1991; Nicholson et al., 1988). Furthermore, $\mathrm{O}_{2}$ is important in the cycling of $\mathrm{Fe}^{3+}$ ions as explained by the following chemical reactions: 


$$
\begin{array}{lll}
\mathrm{FeS}_{2(\mathrm{~s})}+14 \mathrm{Fe}^{3+}+8 \mathrm{H}_{2} \mathrm{O} \longrightarrow & \longrightarrow \mathrm{Fe}^{2+}+2 \mathrm{SO}_{4}{ }^{2-}+16 \mathrm{H}^{+} & \text {Equation 2 } \\
\mathrm{Fe}^{2+}+0.25 \mathrm{O}_{2(\mathrm{aq})}+\mathrm{H}^{+} \longrightarrow \mathrm{Fe}^{3+}+0.25 \mathrm{H}_{2} \mathrm{O} & \text { Equation 3 }
\end{array}
$$

When these two oxidants are present in a system, $\mathrm{Fe}^{3+}$ is more powerful than $\mathrm{O}_{2}$ (Moses et al., 1987). Aside from functioning as a direct oxidant of pyrite, $\mathrm{O}_{2}$ has the additional role of oxidizing $\mathrm{Fe}^{2+}$ ions to $\mathrm{Fe}^{3+}$ ions as shown in Equation 3. However, Equation 3, which is known as the rate determining step of pyrite oxidation, is relatively slow in comparison to Equations 1 and 2 (Singer and Stumm, 1970). This means that both the direct (as oxidant of pyrite) and indirect (as oxidant of $\mathrm{Fe}^{2+}$ ) effects of $\mathrm{O}_{2}$ on pyrite oxidation are minimal in the acidic and circumneutral $\mathrm{pH}$ regions consistent with our results. Towards the alkaline region, the rate of Equation 3 increases dramatically as the $\mathrm{pH}$ increases, but under these conditions $\mathrm{Fe}^{3+}$ is also easily precipitated (Evangelou, 1995). Regardless of these very low concentrations of $\mathrm{Fe}^{3+}$ in the alkaline region, it is still an important oxidant of pyrite as reported by Moses et al. (1987). In addition, $\mathrm{O}_{2}$ becomes more important to replenish the diminishing $\mathrm{Fe}^{3+}$ through $\mathrm{Fe}^{3+} / \mathrm{Fe}^{2+}$ recycling under alkaline conditions because of the very low concentrations of $\mathrm{Fe}^{3+}$ (Moses et al., 1987). Therefore, our results illustrating the importance of $\mathrm{O}_{2}$ in pyrite oxidation especially under alkaline conditions is consistent with these previously published works.

Similarly, the decrease in pyrite oxidation minimized $\mathrm{Pb}$ release from the altered volcanic rock under alkaline-anoxic conditions. In addition, the absence of $\mathrm{O}_{2}$ increased the concentration of $\mathrm{Pb}$ in the leachate between $\mathrm{pH} 4-6$ (Figure 9(b)). This $\mathrm{Pb}$ concentration increase coincided with the increase of $\mathrm{Fe}$ concentration in the leachate in the absence of $\mathrm{O}_{2}$ (Figure 10(a)). Ferric hydroxide starts to precipitate at $\mathrm{pH} 3.5$ while $\mathrm{Fe}^{2+}$ ions start to form oxyhydroxides/oxides at $\mathrm{pH} 4$ depending on the Eh of the system. The results of PHREEQC also showed that $\mathrm{Pb}$ is present between $\mathrm{pH} 4-6$ 
as $\mathrm{Pb}^{2+}$ ion and not as sulfate, oxide or hydroxide under both oxic and anoxic conditions. Thus, the observed increase in $\mathrm{Pb}$ concentration in the absence of $\mathrm{O}_{2}$ in conjunction with $\mathrm{Fe}$ is probably due to the decrease in co-precipitation and/or adsorption of $\mathrm{Pb}$ onto Fe oxyhydroxides/oxides precipitates (Table 13).

In the altered sedimentary rock samples, the leaching behavior of As as a function of $\mathrm{pH}$ changed in three distinct regions under anoxic conditions (Figure 11). In the first region $(\mathrm{pH}<4)$, the concentration of As in the leachate decreased in conjunction with the decrease of $\mathrm{Fe}$ and $\mathrm{Ca}^{2+}$ concentrations. These results indicate that the mobilization of As at acidic $\mathrm{pH}(<4)$ from altered sedimentary rocks is controlled by the dissolution of $\mathrm{Fe}$ and $\mathrm{Ca}$-bearing minerals containing As under both oxic and anoxic conditions. The next region $(\mathrm{pH} 4-8)$ illustrates an increase in the concentration of As in the absence of $\mathrm{O}_{2}$, which could be attributed to the reduced precipitation of Fe-oxyhydroxides/oxides that are important scavengers of As especially in these $\mathrm{pH}$ range (Tables 12 and 13). In the third region $(\mathrm{pH}>8)$, the concentration of As in the leachate decreased because of the retardation of pyrite oxidation similar to that observed in the altered volcanic rocks rich in pyrite. Although the altered sedimentary rock samples contain only trace amounts of pyrite, the decrease of $\mathrm{SO}_{4}{ }^{2-}$ concentration at $\mathrm{pH}$ greater than 8 in the absence of $\mathrm{O}_{2}$ was substantial, which supports our interpretation of pyrite oxidation reduction. These results suggest that pyrite oxidation is an important As release mechanism in hydrothermally altered rocks even if they only contain trace amounts of pyrite.

Conceptualized models of the release mechanisms of $\mathrm{As}$ and $\mathrm{Pb}$ from altered rocks are illustrated in Figures 13 and 14, respectively. The mechanisms controlling the mobilization of As and $\mathrm{Pb}$ from altered rocks with $\mathrm{pH}$ under oxic and anoxic conditions include: dissolution, pyrite oxidation, adsorption/desorption and precipitation and are similar to those proposed under oxic 
conditions. Atmospheric/partial oxidation of pyrite and the subsequent dissolution of soluble As and $\mathrm{Pb}$-bearing phases like $\mathrm{Ca}$ and $\mathrm{Fe}$-sulfates are the dominant leaching mechanisms of $\mathrm{As}$ and $\mathrm{Pb}$ from altered rocks. However, both $\mathrm{As}$ and $\mathrm{Pb}$ are "reactive" solutes whose mobilities are easily affected by changes in the $\mathrm{pH}$ of the altered rock-water system. In the acidic region, acid dissolutions of $\mathrm{Ca}$ and Fe-bearing minerals further contribute to the concentrations of $\mathrm{As}$ and $\mathrm{Pb}$ in the leachate. At the circumneutral $\mathrm{pH}$, As and $\mathrm{Pb}$ mobilities dramatically decrease because of precipitation and adsorption reactions. Finally, $\mathrm{As}$ and $\mathrm{Pb}$ mobilities again increase in the alkaline region because of desorption/enhanced oxidation of pyrite. Pyrite oxidation increase in the alkaline region under abiotic conditions could be related to the availability of surface $\mathrm{OH}^{-}$species that are involved in more rapid electron transfer at the pyrite surface (Evangelou, 1995).

\subsection{Engineering implications}

This study identified the roles of calcite and pyrite in the enrichment and leaching behaviors of As and $\mathrm{Pb}$ in excavated altered rocks. Pyrite is an important source of $\mathrm{As}$ and $\mathrm{Pb}$ in altered rocks and could directly influence the $\mathrm{pH}$ of the rock when in contact with water. On the other hand, the role of calcite in $\mathrm{pH}$ control was more important than as a source of $\mathrm{As}$ and $\mathrm{Pb}$ in our samples, but this may not apply to other hydrothermally altered rock deposits containing calcite. None the less, $\mathrm{pH}$ of the altered rock when in contact with water is dependent on the abundance of these two minerals relative to each other. When altered rocks contain significant amounts of pyrite but the calcite content is negligible, the $\mathrm{pH}$ is acidic. On the other hand, the $\mathrm{pH}$ would be alkaline when calcite is substantial in the rock even with trace amounts of pyrite. Thus, it is possible to categorize excavated hydrothermally altered rocks into pyritic/acidic or calcareous/alkaline rocks, depending on whether they contain significant sulfide minerals (e.g., pyrite) or carbonate minerals (e.g., calcite) and their $\mathrm{pH}$ in water. With this simple classification based on the mineralogy and $\mathrm{pH}$ of the excavated 
altered rocks, countermeasures for their disposal can be created separately through the enhancement or retardation of the main mechanism/s that control the mobilities of As and $\mathrm{Pb}$. Moreover, pyritic rocks should be disposed of immediately after excavation to prevent the partial oxidation of pyrite and the formation of soluble minerals that could lower the $\mathrm{pH}$ and enhance the mobilization of heavy metals like $\mathrm{Pb}$. If this is not possible, the interim storage sites of these excavated rocks must be covered to minimize their exposure to moisture and rain. Our results also indicate that the best way to immobilize $\mathrm{As}$ and $\mathrm{Pb}$ is through the enhancement of adsorption and precipitation processes, respectively and these processes must be incorporated into the design of the alternative disposal method. Finally, because the mobilization mechanisms of $\mathrm{As}$ and $\mathrm{Pb}$ are strongly $\mathrm{pH}$-dependent but do not dramatically change under oxic and anoxic conditions, $\mathrm{pH}$ of the altered rock-water system must be closely controlled during the actual disposal of the rock.

\section{Conclusions}

Hydrothermally altered rocks contain elevated amounts of $\mathrm{As}$ and $\mathrm{Pb}$ that are easily mobilized under various conditions encountered in the environment. Enrichment of these rocks with As and $\mathrm{Pb}$ predominantly occurred within and around precipitated pyrite crystals and not on the surrounding alumino-silicate minerals. However, the $\mathrm{As}$ and $\mathrm{Pb}$ contents of pyrite formed in these altered rocks varied depending on the inherent physical and chemical properties of the hydrothermal solution that caused the alteration. Dissolution of soluble $\mathrm{Ca}$ and Fe-phases, which are mostly products of the atmospheric/partial oxidation of pyrite, is the dominant leaching mechanism of As and $\mathrm{Pb}$. However, changes in the $\mathrm{pH}$ of the rock-water system could increase the contributions of the other mechanisms like pyrite oxidation, adsorption/desorption and precipitation/co-precipitation reactions to the equilibrium concentration of $\mathrm{As}$ and $\mathrm{Pb}$ in the leachate. The leaching behaviors of As and $\mathrm{Pb}$ were both $\mathrm{pH}$ dependent with or without $\mathrm{O}_{2}$ and $\mathrm{CO}_{2}$. The absence of $\mathrm{O}_{2}$ also minimized 
the mobilization of $\mathrm{As}$ and $\mathrm{Pb}$ especially in the alkaline region because pyrite oxidation was retarded but not in the acidic and circumneutral $\mathrm{pH}$. The $\mathrm{pH}$ and the leaching behaviors of As and $\mathrm{Pb}$ also depended on the relative abundance of pyrite and calcite in the rock. Thus, the classification scheme outlined in this paper using pyrite and calcite as "indicators" could be used to group together excavated rocks with complex mineral properties and from different locations. Moreover, the mechanisms of $\mathrm{As}$ and $\mathrm{Pb}$ release from altered rocks could be predicted based on the relative abundance of pyrite and calcite as well as the $\mathrm{pH}$ of the altered rock when in contact with water.

\section{Acknowledgments}

The authors wish to thank the support of Earth Science Co., Ltd. and Shimadzu Analytical and Measuring Center, Inc. in the microscopic observations and the EPMA analysis of the samples. The authors also wish to thank the anonymous reviewers for their valuable inputs to this paper.

\section{References}

Acharyya, S.K., Lahiri, S., Raymahashay, B.C., Bhowmik, A., 2000. Arsenic toxicity of groundwater in parts of the Bengal basin in India and Bangladesh: the role of Quarternary stratigraphy and Holecene sea level-fluctuation. Environmental Geology 39(10), 1127-1137.

Aiuppa, A., Avino, R., Brusca, L., Caliro, S., Chiodini, G., D’Alessadro, W., Favara, R., Federico, C., Ginevra, W., Inguaggiato, S., Longo, M., Pecoraino, G., Valenza, M., 2006. Mineral control of arsenic content in thermal waters from volcano-hosted hydrothermal systems: Insights from the island of Ischia and Phlegrean Fields. Chemical Geology 229, 313 - 330.

Akai, J., Izumi, K., Fukuhara, H., Masuda, H., Nakano, S., Yoshimura, T., Ohfuji, H., Anwar, H.M., Akai, K., 2004. Mineralogical and geomicrobial investigations on groundwater arsenic enrichment in Bangladesh. Applied Geochemistry 19, 215-230.

Allen, K.D., Hahn, G.A., 1994. Geology of Sunbeam and Grouse Creek gold-silver deposits, Yankee Fork mining district, Eocene Challis volcanic field, Idaho: a volcanic dome and volcaniclastic-hosted epithermal system. Econ. Geol. 89, 1964-1982.

Alt, J.C., Jiang, W.T., 1991. Hydrothermally precipitated mixed-layer illite-smectite in recent massive deposits from the sea floor. Geology 19, 570-573. 
Apello, C.A.J., Postma, D., 2005. Geochemistry, Groundwater and Pollution, $2^{\text {nd }}$ ed., A.A. Balkema Publishers, London.

Bethke, C.M., 1992. The Geochemist's Workbench - A User's guide to Rxn, Act2, Tact, React and Gtplot. University of Illinois, Urbana, Illinois.

Bostick, B.C., Fendorf, S., 2003. Arsenite sorption on troilite (FeS) and pyrite (FeS2). Geochim. Cosmochim. Acta 67, 909-921.

Bowell, R.J., 1993. Mineralogy and geochemistry of tropical rain forest soils: Ashanti, Ghana. Chemical Geology 106, 345-348.

Brannon, J.M., Patrick, W.H., 1987. Fixation, transformation and mobilization of arsenic in sediments. Environ. Sci. Technol. 21, 450-459.

Burgess, W.G., Hoque, M.A., Michael, H.A., Voss, C.I., Breit, G.N., Ahmed, K.M., 2010. Vulnerability of deep groundwater in the Bengal Aquifer System to contamination by arsenic. Nature Geoscience 3, 83-87.

Choprapawon, C., Rodcline, A., 1997. Chronic arsenic poisoning in Ronpibool Nakhon Sri Thammarat, the southern province of Thailand, in: Abernathy, C.O., Calderon, R.L., Chappell, W.R. (Eds.), Arsenic Exposure and Health Effects, Chapman and Hall, London, pp. 69-77.

Cornelis, G., Anette-Johnson, C., Van Gerven, T., Vandecasteele, C., 2008. Leaching mechanisms of oxyanionic metalloid and metal species in alkaline solid wastes: A review. Applied Geochemistry 23, 955-976.

Das, D., Samanta, S., Mandal, B.K., Chowdhury, T.R., Chanda, C.R., Chowdry, P.P., Basu, G.K., Chakraborti, D., 1996. Arsenic in groundwater in six districts of West Bengal, India. Environmental Geochemistry and Health 8, 5-15.

De Carlo, E.H., McMurtry, G. M., Yeh, H.W., 1983. Geochemistry of hydrothermal deposits from Loihi submarine volcano, Hawaii. Earth and the Planetary Science Letters 66, 438-449.

De Donato, P., Mustin, C., Benoit, R., Erre, R., 1993. Spatial distribution of iron and sulphur species on the surface of pyrite. Applied Surface Science 68, 81 - 93.

Dekov, V.M., Cuadros, J., Shanks, W.C., Koski, R.A., 2008. Deposition of talc - kerolite - smectite - smectite at seafloor hydrothermal vent fields: Evidence from mineralogical, geochemical and oxygen isotope studies. Chemical Geology 247, 171-194.

Dermatas, D., Menounou, N., Dadachov, D.O., Shen, M. G., Xu, X., Tsaneva, V., 2006. Lead leachability in firing range soils. Environmental Engineering Science 23(1), 88-101.

Dousova, B., Machovic, V., Kolousek, D., Kovanda, F., Dornicak, V., 2003. Sorption of As (V) species from aqueous solution. Water Air and Soil Pollution 149, 251-267. 
Dowling, C.B., Poreda, R.J., Basu, A.R., Peters, S.L., Aggarwal, P.K., 2002. Geochemical study of arsenic release mechanisms in the Bengal Basin groundwater. Water Resources Research 38(9), 1173.

Evangelou, V.P., 1995. Pyrite oxidation and its control, CRC Press, New York.

Fleet, M.E., MacLean, P.J., Barbier, J., 1989. Oscillatory-zoned As-bearing pyrite from stratabound and stratiform gold deposits: An indicator of ore fluid evolution. Economic Geology Monograph 6, 356-362.

Franzson, H., Zierenberg, R., Schiffman, P., 2008. Chemical transport in geothermal systems in Iceland: Evidence from hydrothermal alteration. Journal of Volcanology and Geothermal Research $173,217-229$.

Ghosh, M.M., Teoh, R.S., 1985. Adsorption of arsenic on hydrous aluminum oxide. In Proc. $7^{\text {th }}$ Mid-Atlantic Industrial Waste Conference, Lancaster, PA, 139-155.

Halbach, P., Pracejus, B., Marten, A., 1993. Geology and mineralogy of massive sulfide ores from Okinawa trough, Japan. Econ. Geol. 88, 2210-2225.

Hammond, P.B., 1977. Exposures of humans to lead. Annu. Rev. Pharmacol. Toxicol. 17, 197-214.

Holmes, P.R., Crundwell, F.K., 2000. The kinetics of the oxidation of pyrite by ferric ions and dissolved oxygen: An electrochemical study. Geochim. Cosmochim. Acta 64, 263-274.

Horton, T.W., Becker, J.A., Craw, D., Koons, P.O., Page Chamberlain, C., 2001. Hydrothermal arsenic enrichment in an active mountain belt: Southern Apls, New Zealand. Chemical Geology $177,323-339$.

Huston, D.L., Sie, S.H., Sauter, G.F., Cook, D.R., Both, R.A., 1995. Trace elements in sulfide minerals from eastern Australian volcanic-hosted massive sulfide deposits: Part 1. Proton microprobe analyses of pyrite, chalcopyrite and sphalerite, and Part 2. Selenium levels in pyrite: Comparison with $\delta^{34} \mathrm{~S}$ values and implications for the source of sulfur in volcanogenic hydrothermal systems. Econ. Geol. 90, 1167-1196.

Igarashi, T., Imagawa, H., Uchiyama, H., Asakura, K., 2008. Leaching behavior of arsenic from various rocks by controlling geochemical conditions. Miner. Eng. 21, 191-199.

Imagawa, H., Igarashi, T., Uchiyama, H., Asakura, K., 2007. Leaching behavior of arsenic from altered igneous rocks by batch method. Journal of the Mining and Materials Processing Institute of Japan 123, 158-164. (Paper is written in Japanese with English abstract)

Kirk, M.F., Holm, T.R., Park, J., Jin, Q., Sanford, R.A., Fouke, B.W., Bethke, C.M., 2004. Bacterial sulfate reduction limits natural arsenic contamination in groundwater. Geology 32, 953-956.

Kisch, H.J., 1983. Mineralogy and petrology of burial diagenesis (burial metamorphism) and incipient metamorphism in clastic rocks, in: Larsen, G., Chilingar, G.V., (Eds.), Diagenesis in sediments and sedimentary rocks 2, Elsevier, Amsterdam, pp.289-493. 
Lin, Z., Puls, R.W., 2000. Adsorption, desorption and oxidation of arsenic affected by clay minerals and aging process. Environmental Geology 39(7), 753-759.

Lowers, H.A., Breit, G.N., Foster, A.L., Whitney, J., Yount, J., Uddin, M.N., Muneem, A.A., 2007. Arsenic incorporation into authigenic pyrite, Bengal Basin sediment, Bangladesh. Geochim. Cosmochim. Acta 71, $2699-2717$.

Marques, J.M., Matias, M.J., Basto, M.J., Carreira, P.M., Aires-Barros, L.A., Goff, F.E., 2010. Hydrothermal alteration of Hercynian granites, its significance to the evolution of geothermal systems in granitic rocks. Geothermics 39, 152-160.

Martin-Crespo, T., Vindel, E., Lopez-Garcia, J.A., Cardellach, E., 2004. As-(Ag) sulphide veins in the Spanish central system: Further evidence for a hydrothermal event of Permian age. Ore Geology Reviews 25, 199-219.

McKibben M.A., Barnes H.L., 1986. Oxidation of pyrite in low temperature acidic solutions: Rate laws and surface textures. Geochim. Cosmochim. Acta 50, 1509-1520.

Moore, J.N., Ficklin, W.H., Johns, C., 1988. Partitioning of arsenic and metals in reducing sediments. Environ. Sci. Technol. 22, 432-437.

Moore, M.R., Goldberg, A., 1985. Health implications of the hematopoietic effect of lead, in: Mahaffey, K.R. (Ed.), Dietary and Environmental Lead: Human Health Effects, Elsevier, Amsterdam, pp. 260-314.

Moses, C.O., Herman, J.S., 1991. Pyrite oxidation at circumneutral pH. Geochim. Cosmochim. Acta 55, 471-482.

Moses, C.O., Nordstrom, D.K., Herman, J.S., Mills, A., 1987. Aqueous pyrite oxidation by dissolved oxygen and by ferric iron. Geochem. Cosmochim. Acta 54, 1561-1572.

Nicholson, R.V., Gillham, R.W., and Reardon, E.J., 1988. Pyrite oxidation in carbonate-buffered solution: 1. Experimental kinetics. Geochim. Cosmochim. Acta 52, 1077-1085.

Nickson, R.T., McArthur, K.M., Ravenscroft, J.M., Burgess, W.G., Ahmed, K.M., 2000.

Mechanism of arsenic release to groundwater, Bangladesh and West Bengal. Applied Geochemistry $15,403-413$.

O’Day, P.A., Vlassopoulos, D., Root, R., Rivera, N., 2004. The influence of sulfur and iron on dissolved arsenic concentrations in the shallow subsurface under changing redox conditions, Proceedings of the National Academy of Sciences 101 [38], 13703-13708.

Ostwald, J., England, B.M., 1977. Notes on framboidal pyrite from Allandale, New South Wales, Australia. Mineral. Deposita 12, 111-116.

Parkhurst, D.L., Appelo, C.A.J., 1999. User's Guide to PHREEQC (Version 2) - A computer program for speciation, batch-reactions, one-dimensional transport, and inverse geochemical calculations. U.S. Geological Survey, Denver, CO. 
Peters, S.C., Blum, J.D., 2003. The source and transport of arsenic in a bedrock aquifer, New Hampshire, USA. Applied Geochemistry 18, 1773-1787.

Pirajno, F., 2009. Hydrothermal Processes and Mineral Systems. Springer Science, The Netherlands.

Pokrovski, G.S., Borisova, A.Y., Harrichoury, J.C., 2007. The effect of sulfur on vapor-liquid fractionation of metals in hydrothermal systems. Earth and Planetary Science Letters 266, 345-362.

Rabinowitz, B.M., 2005. Lead isotopes in soils near five historic American lead smelters and refineries. Science and Total Environment 346, 138-148.

Savage, K.S., Tingle, T.N., O’Day, P.A., Waychunas, G.A., Bird, D.K., 2000. Arsenic speciation in pyrite and secondary weathering phases, Mother Lode Gold District, Tuolumne County, California. Applied Geochemistry 15, 1219-1244.

Schaufuss, A.G., Nesbitt, H.W., Kartio, I., Laajalehto, K., Bancroft, G.M., Szargan, R., 1998. Reactivity of surface chemical states on fractured pyrite. Surface Science 411 (3), 321-328.

Sengupta, A.K., 2002. Environmental Separation of Heavy Metals - Engineering Processes. Lewis Publishers, London.

Singer, P.C., Stumm, W., 1970. Acidic mine drainage: The rate-determining step. Science 167, 1121-1123.

Smedley, P.L., Kinniburgh, D.G., 2002. A review of the source, behavior and distribution of arsenic in natural waters. Applied Geochemistry 17, 517-568.

Srodon, J., Eberl, D.D., 1984. Illite, in: Bailey, S.W., (Ed.), Micas: Reviews in Mineralogy Vol. 13, Mineralogical Society of America, Washington D.C., pp.495-544.

Tabelin, C.B., Igarashi, T., 2009. Mechanisms of arsenic and lead release from hydrothermally altered rock. Journal of Hazardous Materials 169, 980-990.

Tabelin, C.B., Igarashi, T., Tamoto, S., 2010. Factors affecting arsenic mobility from hydrothermally altered rock in impoundment-type in situ experiments. Miner. Eng. 23, 238-248.

Tabelin, C.B., Igarashi, T., Takahashi, R., 2012a. Mobilization and speciation of arsenic from hydrothermally altered rock in laboratory column experiments under ambient conditions. Applied Geochemistry 27, 326-342.

Tabelin, C.B., Basri, A.H.M., Igarashi, T., Yoneda, T., 2012b. Removal of arsenic, boron and selenium from excavated rocks by consecutive washing. Water, Air, \& Soil Pollution 223, 41534167.

Tatsuhara, T., Arima, T., Igarashi, T., Tabelin, C.B., 2012. Combined neutralization-adsorption system for the disposal of hydrothermally altered excavated rock producing acidic leachate with hazardous elements. Engineering Geology 139-140, 76-84. 
Todd, E.C., Sherman, D.M., Purton, J.A., 2003. Surface oxidation of pyrite under ambient atmospheric and aqueous ( $\mathrm{pH}=2$ to 10 ) conditions: Electronic structure and mineralogy from $\mathrm{X}$ ray absorption spectroscopy. Geochim. Cosmochim. Acta 67(5), 881-893.

Ure, A., Berrow, M., 1982. Chapter 3: The elemental constituents of soils, in: Bowen, H.J.M., (Ed.), Environmental Chemistry, Royal Society of Chemistry, London, pp. 94-203.

Wang, S., Mulligan, C., 2006. Natural attenuation processes for remediation of arsenic contaminated soils and groundwater. Journal of Hazardous Materials 138(3), 459-470.

Weise, R.G., Fyfe, W.S., 1986. Occurrences of iron sulfides in Ohio coals. Int. J. Coal Geol. 6, 251276.

Welch, A.H., Helsel, D.R., Focazio, M.J., Watkins, S.A., 1999. Arsenic in ground water supplies of the United States, in: Chappell, W.R., Abernathy, C.O., Calderon, R.L. (Eds.), Arsenic Exposure and Health Effects, Elsevier, Amsterdam, pp. 9-17.

Williams, M., 1997. Mining-related arsenic hazards: Thailand case study, Summary Report, Brit. Geol. Surv. Tech. Rep. WC/97/49. 


\section{FIGURE CAPTIONS}

FIGURE 1 Photomicrographs taken with open (a) and crossed (b) Nicols showing the minerals present around and away from the zone of alteration in sample SR3 (altered sedimentary rock).

FIGURE 2 Photomicrographs taken with open Nicols (reflected light) showing the minerals present in the unaltered zone of sample SR3 (altered sedimentary rock).

FIGURE 3 Photomicrographs taken with open Nicols (polarized light) (a) and SEM (b) showing the minerals present in the zone of alteration and the morphology of pyrite in sample SR3 (altered sedimentary rock).

FIGURE 4 Photomicrographs taken with open Nicol (polarized light) (a) and SEM (b) showing the minerals present in the altered volcanic rock samples and the morphology of pyrite.

FIGURE 5 The elemental maps of Fe (a), S (b), As (c), Si (d), and Al (e) from the altered volcanic rock at a magnification of $40 \mu \mathrm{m}$ modified with permission from the Journal of the Mining and Materials Processing Institute of Japan (Imagawa et al., 2007).

FIGURE 6 As concentrations in the leachate as a function of $\mathrm{pH}$ under oxic conditions: altered volcanic rocks (a) and altered sedimentary rocks (b).

FIGURE $7 \quad \mathrm{SO}_{4}{ }^{2-}$ concentrations in the leachate as a function of $\mathrm{pH}$ under oxic conditions: altered volcanic rocks (a) and altered sedimentary rocks (b).

FIGURE 8 Pb concentrations in the leachate of the altered volcanic rock samples as a function of $\mathrm{pH}$ under oxic conditions.

FIGURE 9 As and $\mathrm{Pb}$ concentrations in the leachate of altered volcanic rocks under anoxic conditions: As concentration as a function of $\mathrm{pH}$ (a) and $\mathrm{Pb}$ concentration as a function of $\mathrm{pH}(\mathrm{b})$.

FIGURE $10 \mathrm{Fe}$ and $\mathrm{SO}_{4}{ }^{2-}$ concentrations in the leachate of altered volcanic rocks under anoxic conditions: Fe concentration as a function of $\mathrm{pH}$ (a) and $\mathrm{SO}_{4}{ }^{2-}$ concentration as a function of $\mathrm{pH}(\mathrm{b})$.

FIGURE 11 As concentration in the leachate of altered sedimentary rocks under anoxic conditions.

FIGURE $12 \mathrm{Fe}, \mathrm{Ca}^{2+}$ and $\mathrm{SO}_{4}{ }^{2-}$ concentrations in the leachate of altered sedimentary rocks under anoxic conditions: Fe concentration as a function of $\mathrm{pH}(\mathrm{a}), \mathrm{Ca}^{2+}$ concentration as a function of $\mathrm{pH}$ (b) and $\mathrm{SO}_{4}{ }^{2-}$ concentration as a function of $\mathrm{pH}(\mathrm{c})$.

FIGURE 13 A conceptual model of the mechanisms of As release from altered rocks with $\mathrm{pH}$.

FIGURE 14 A conceptual model of the mechanisms of $\mathrm{Pb}$ release from altered rocks with $\mathrm{pH}$. 


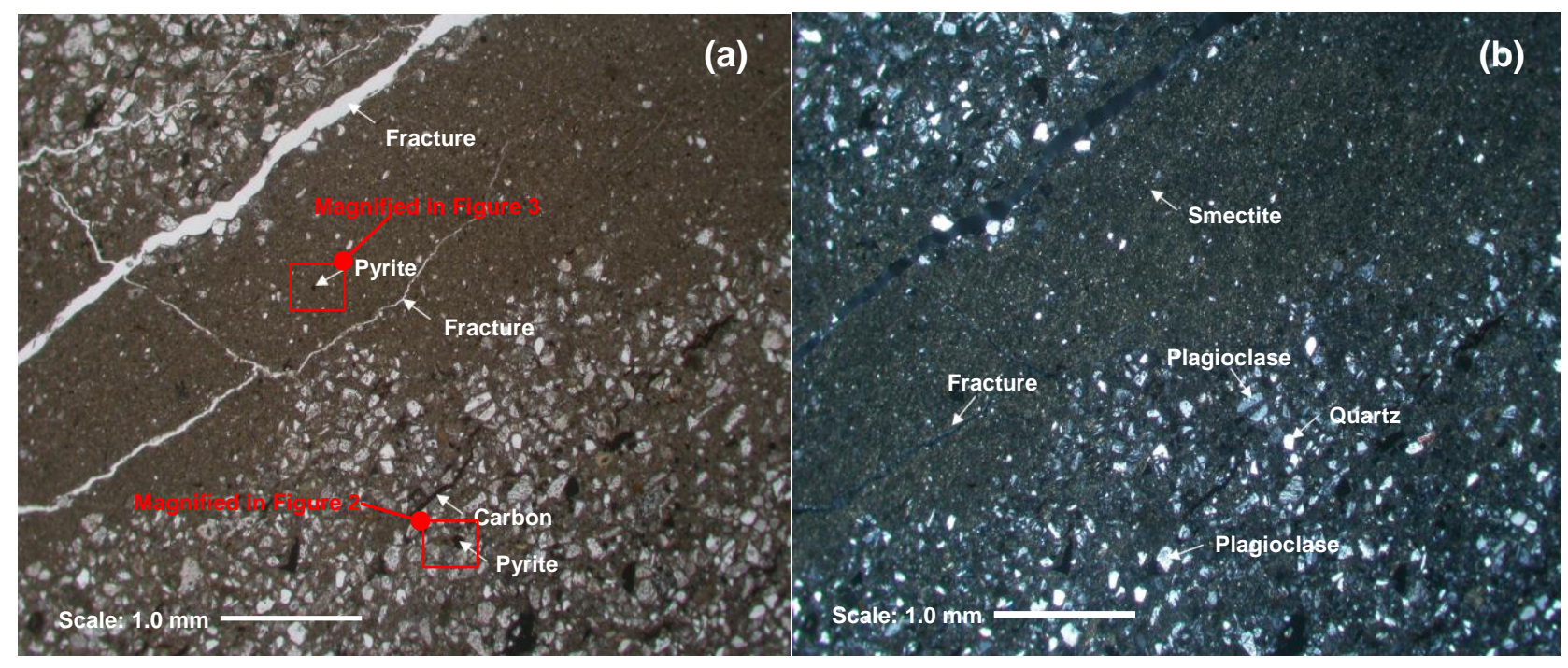

Figure 1

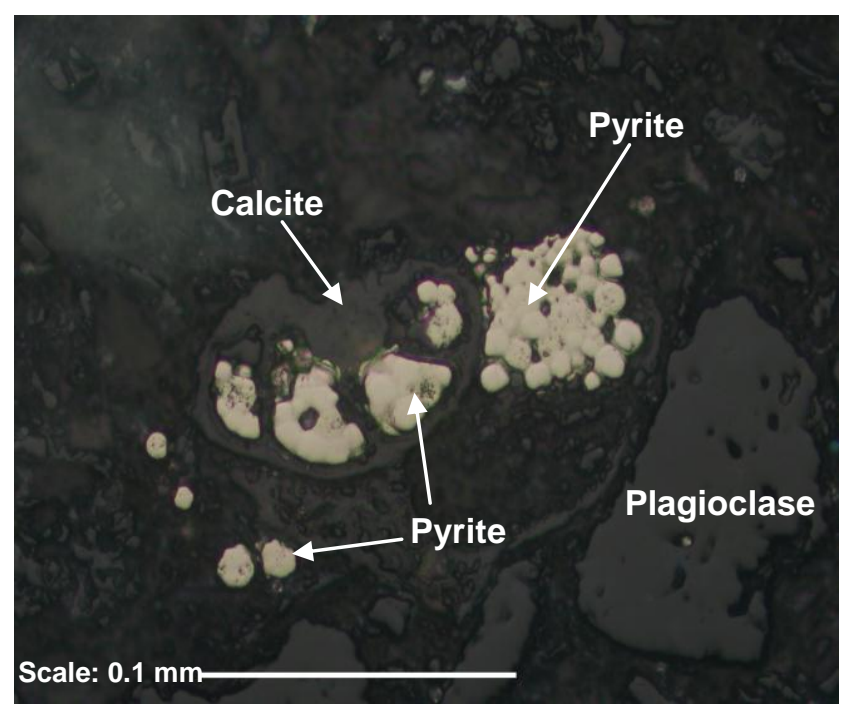

Figure 2 


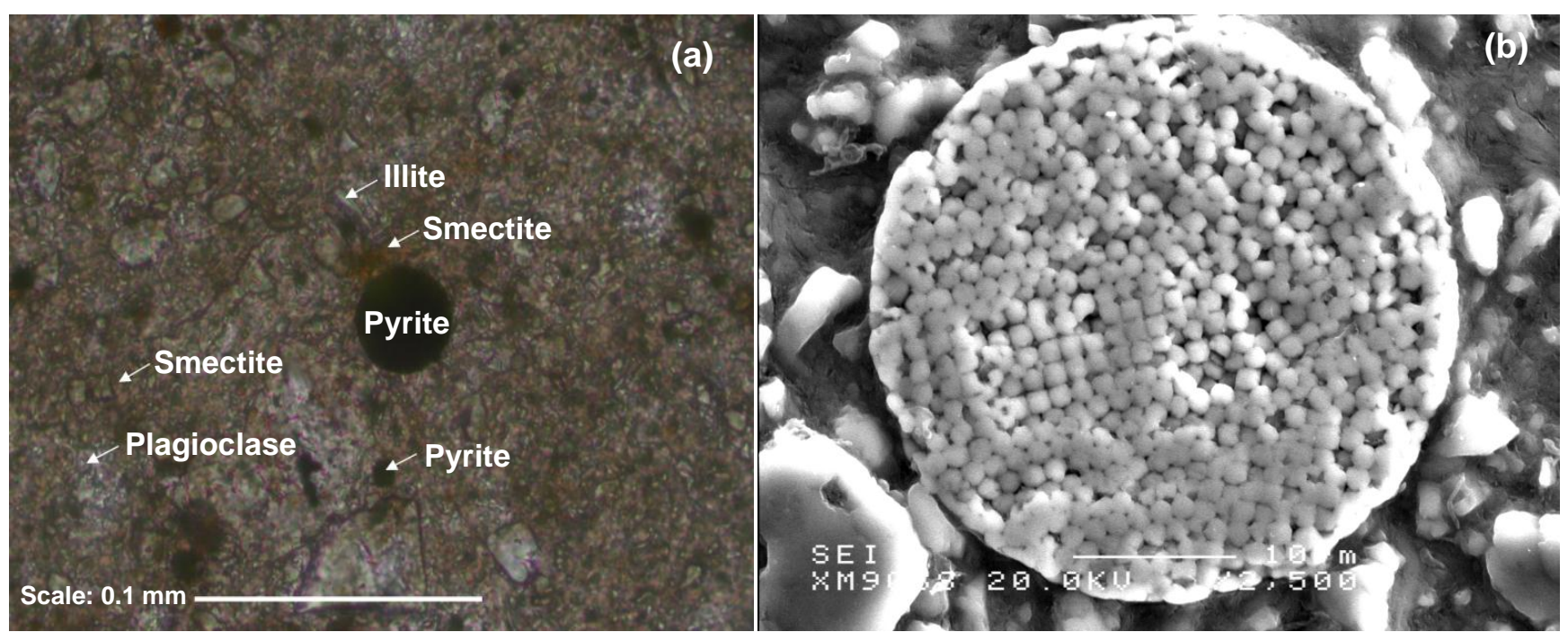

Figure 3
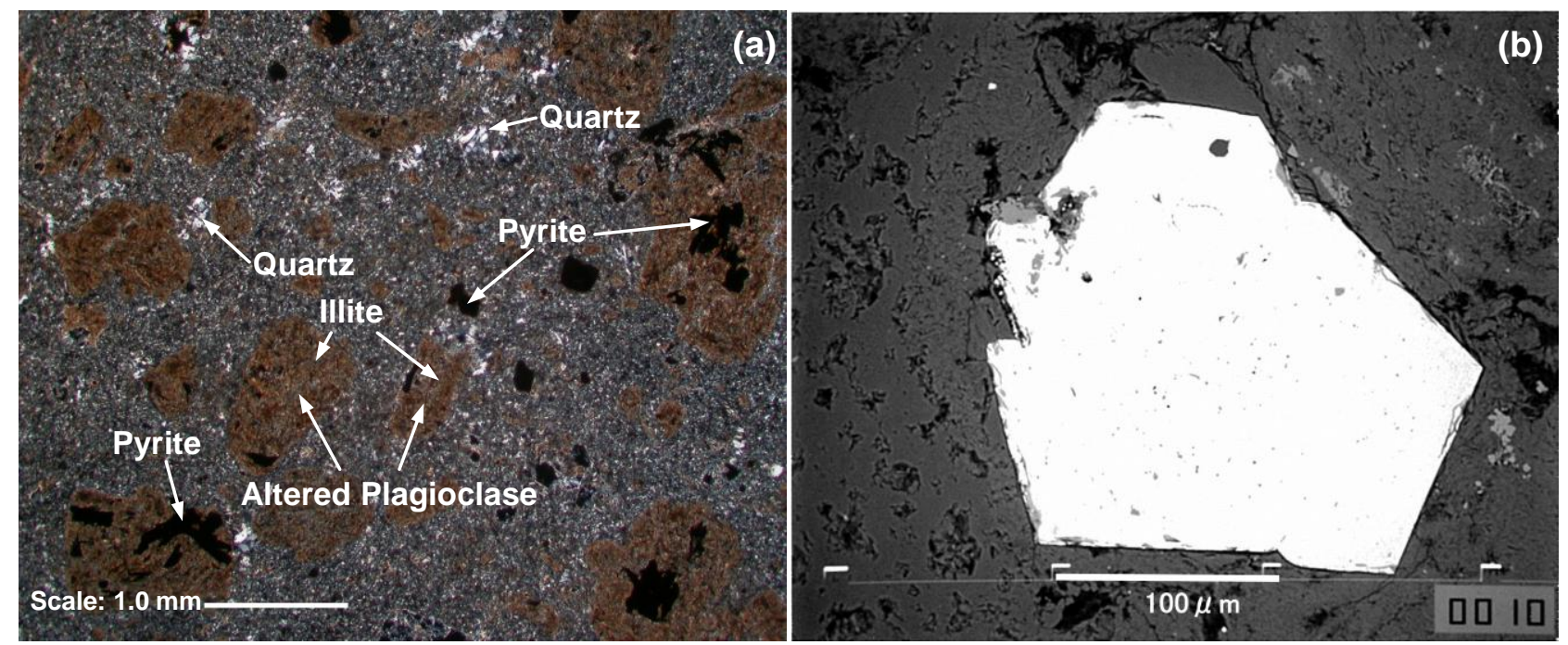

Figure 4 

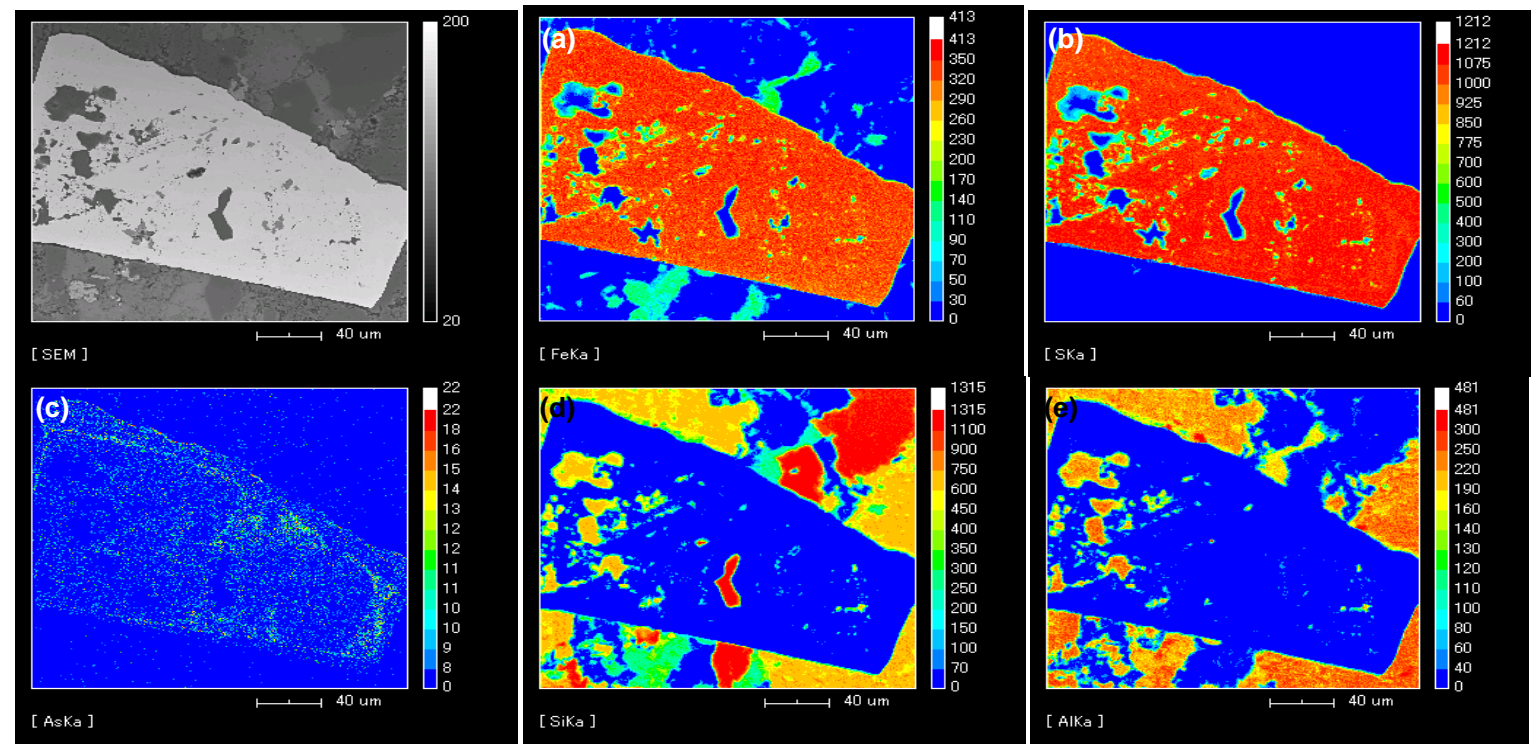

Figure 5
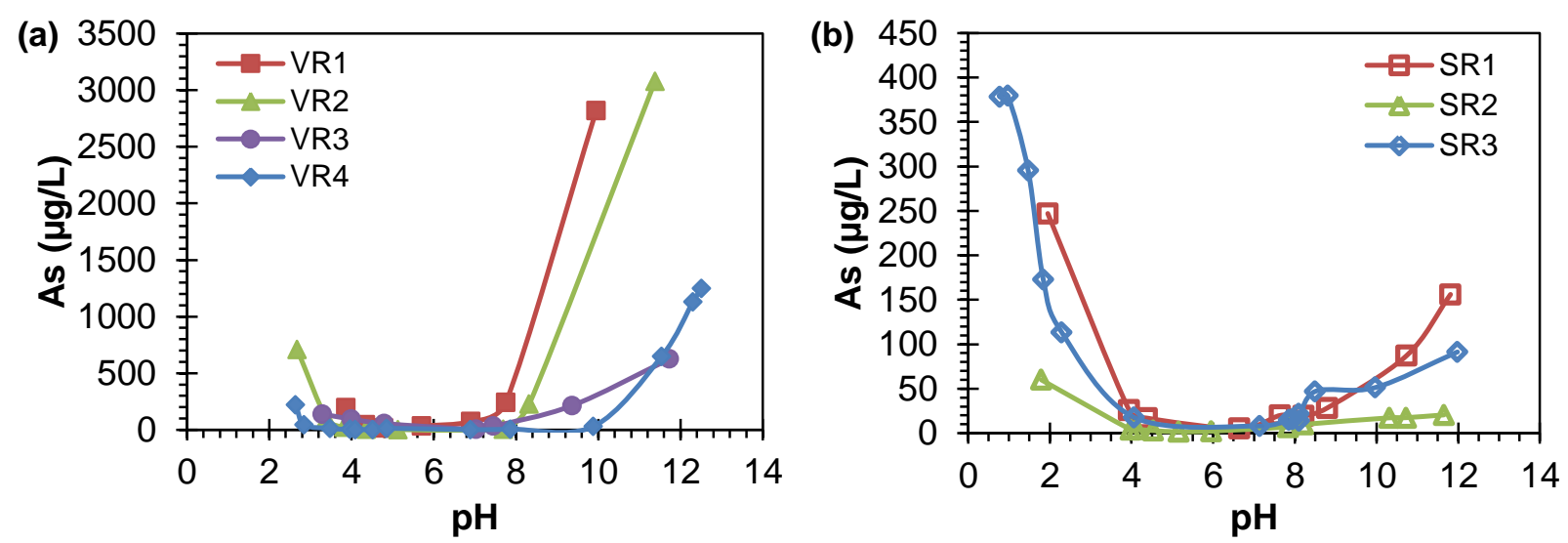

Figure 6 

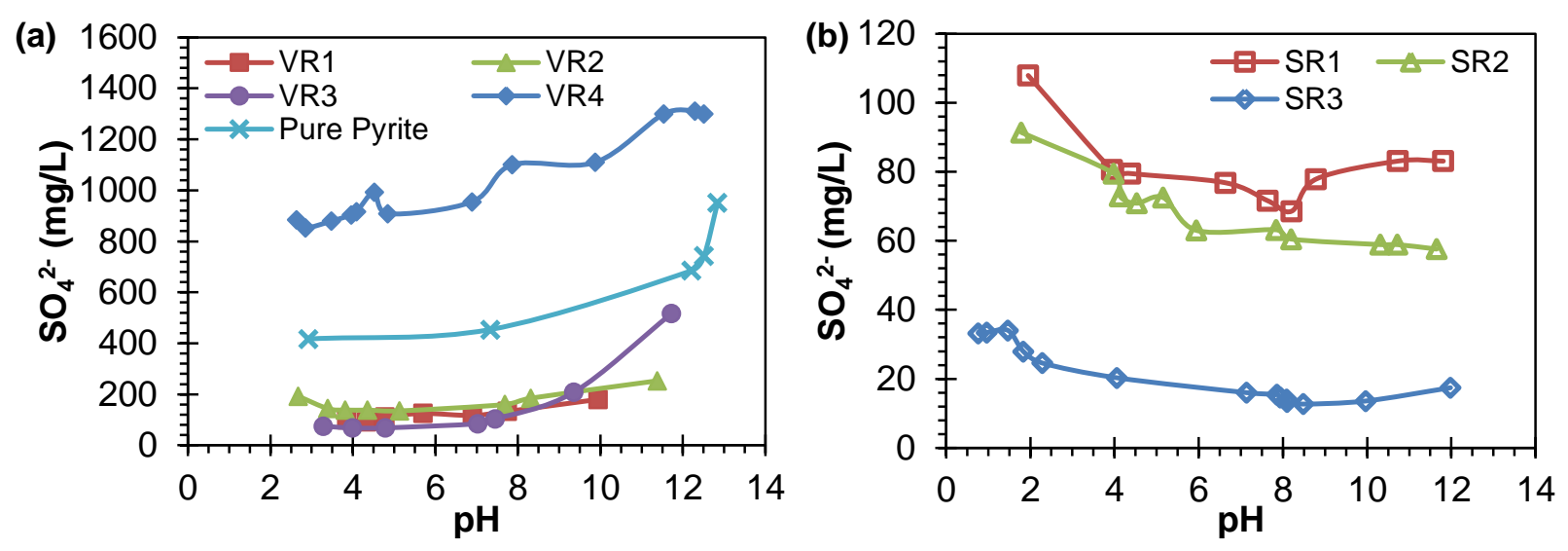

Figure 7

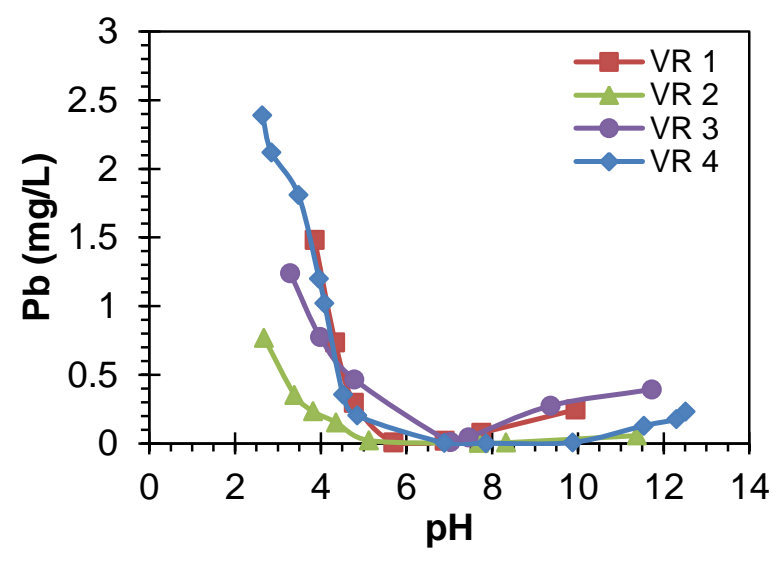

Figure 8 

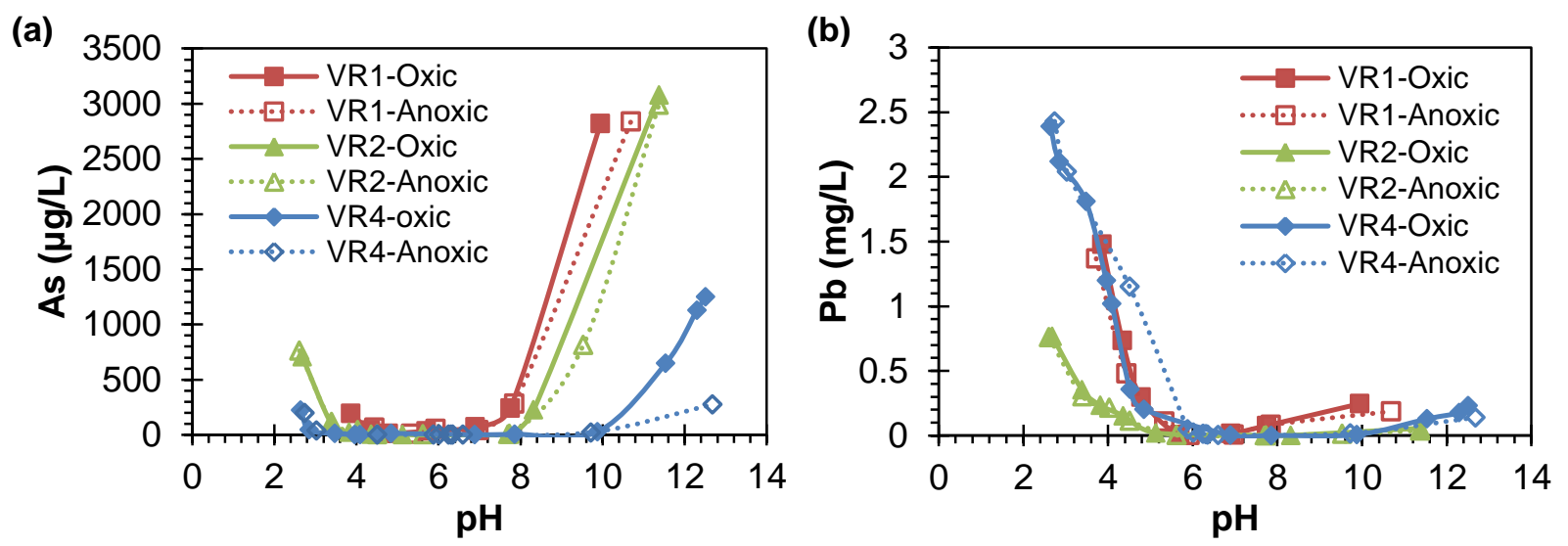

Figure 9
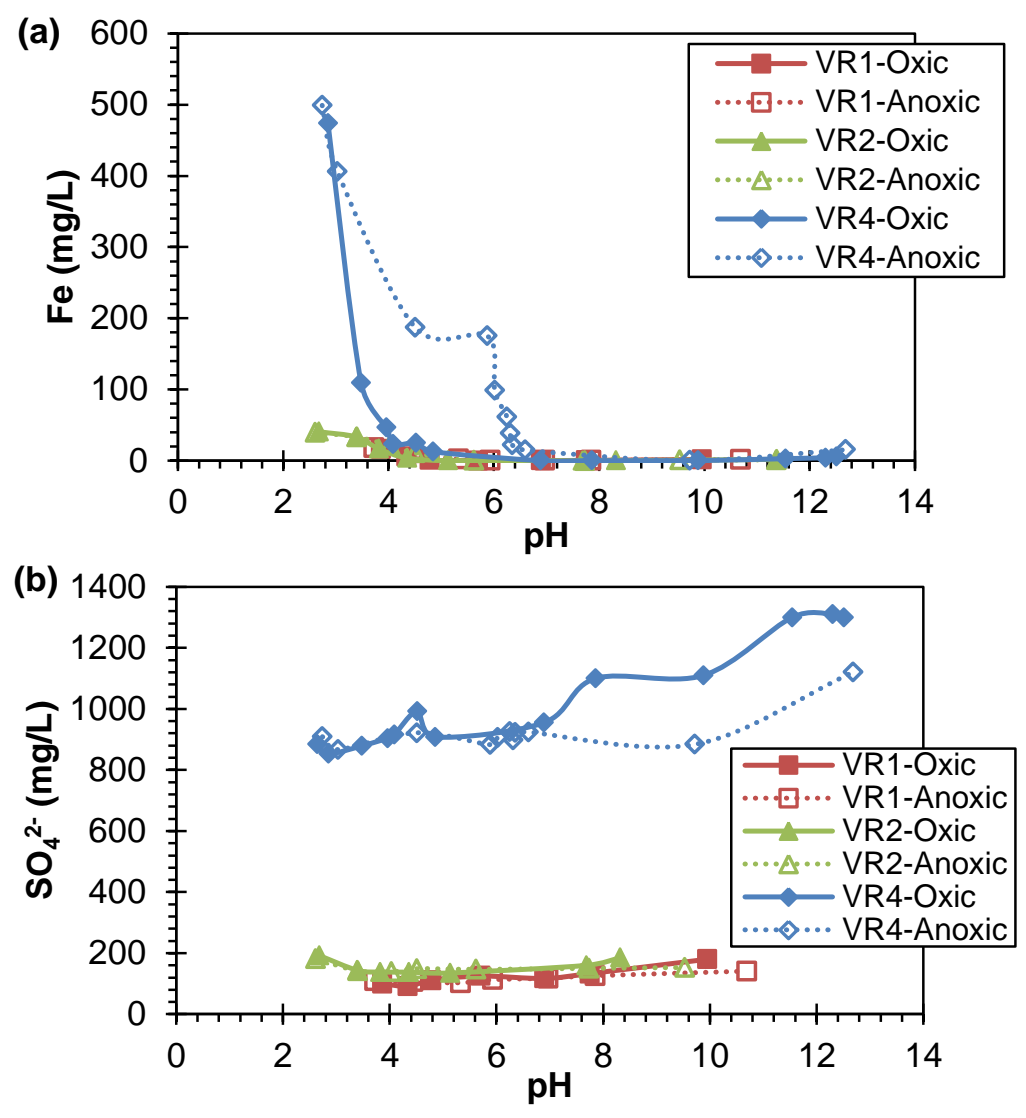

Figure 10 


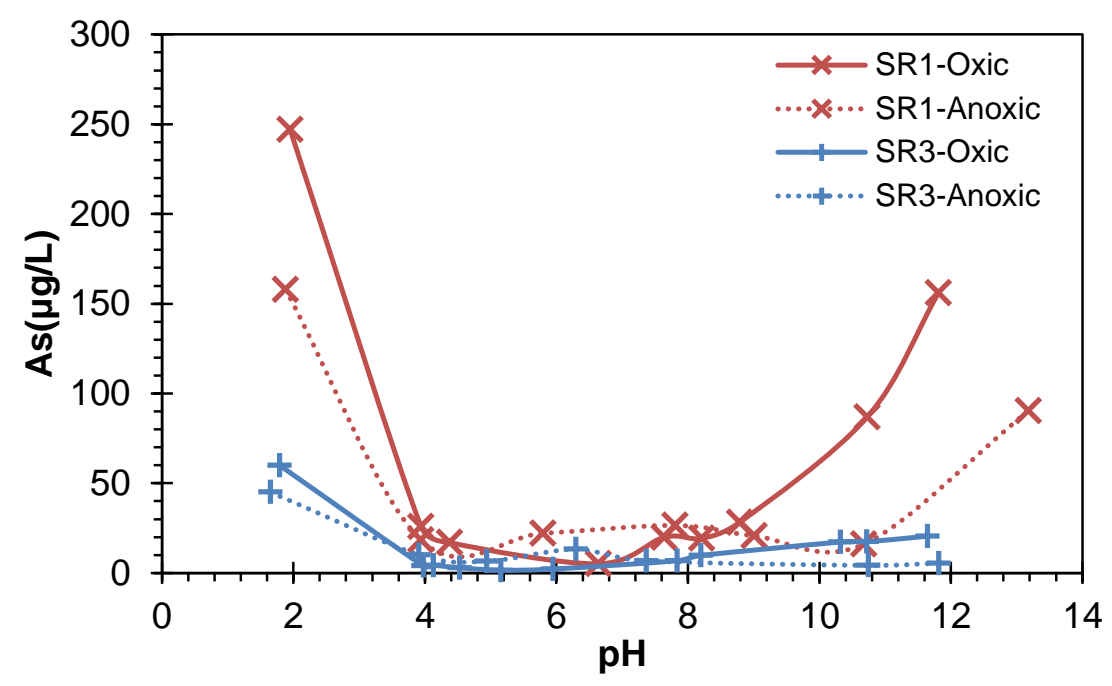

Figure 11
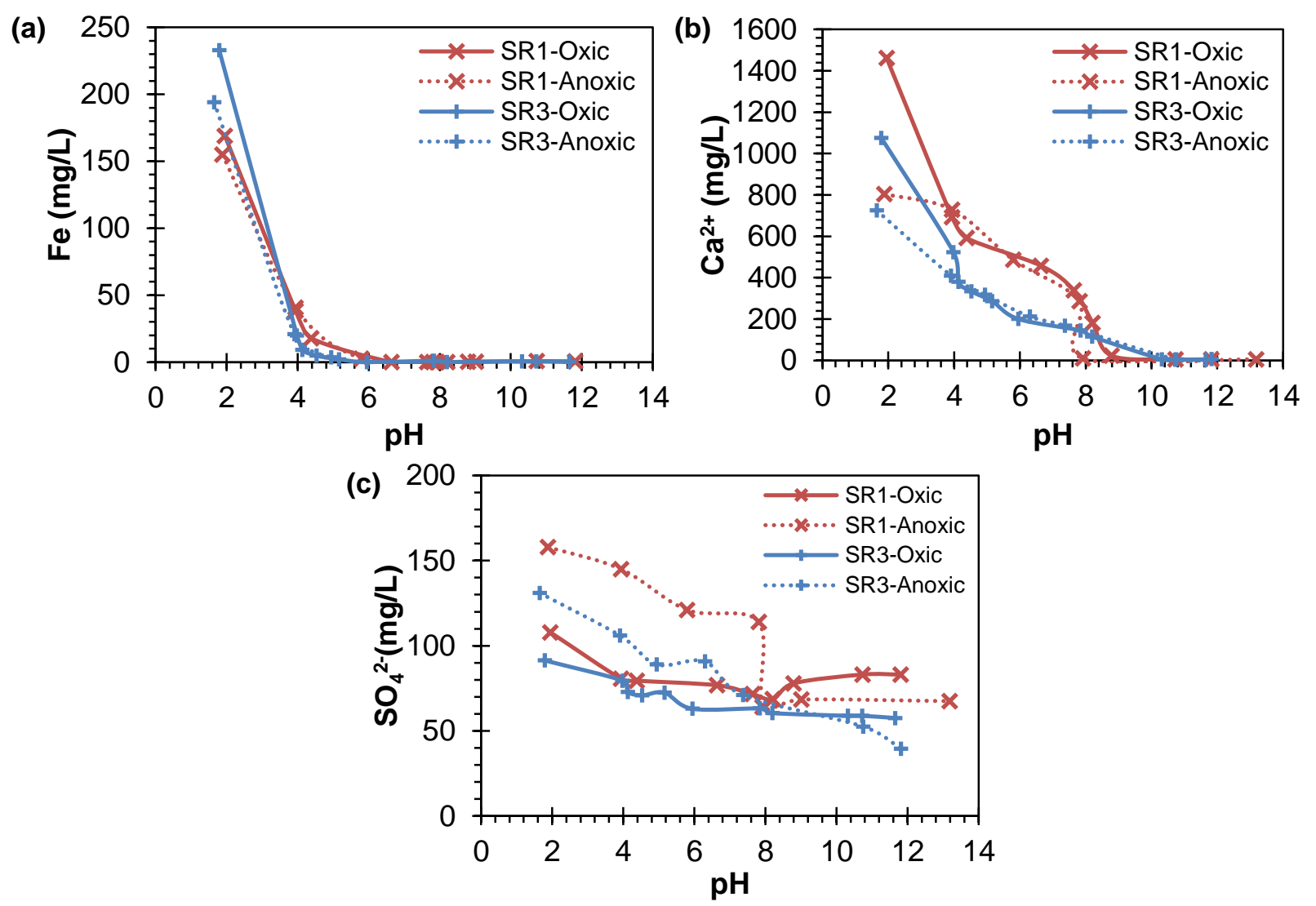

Figure 12 


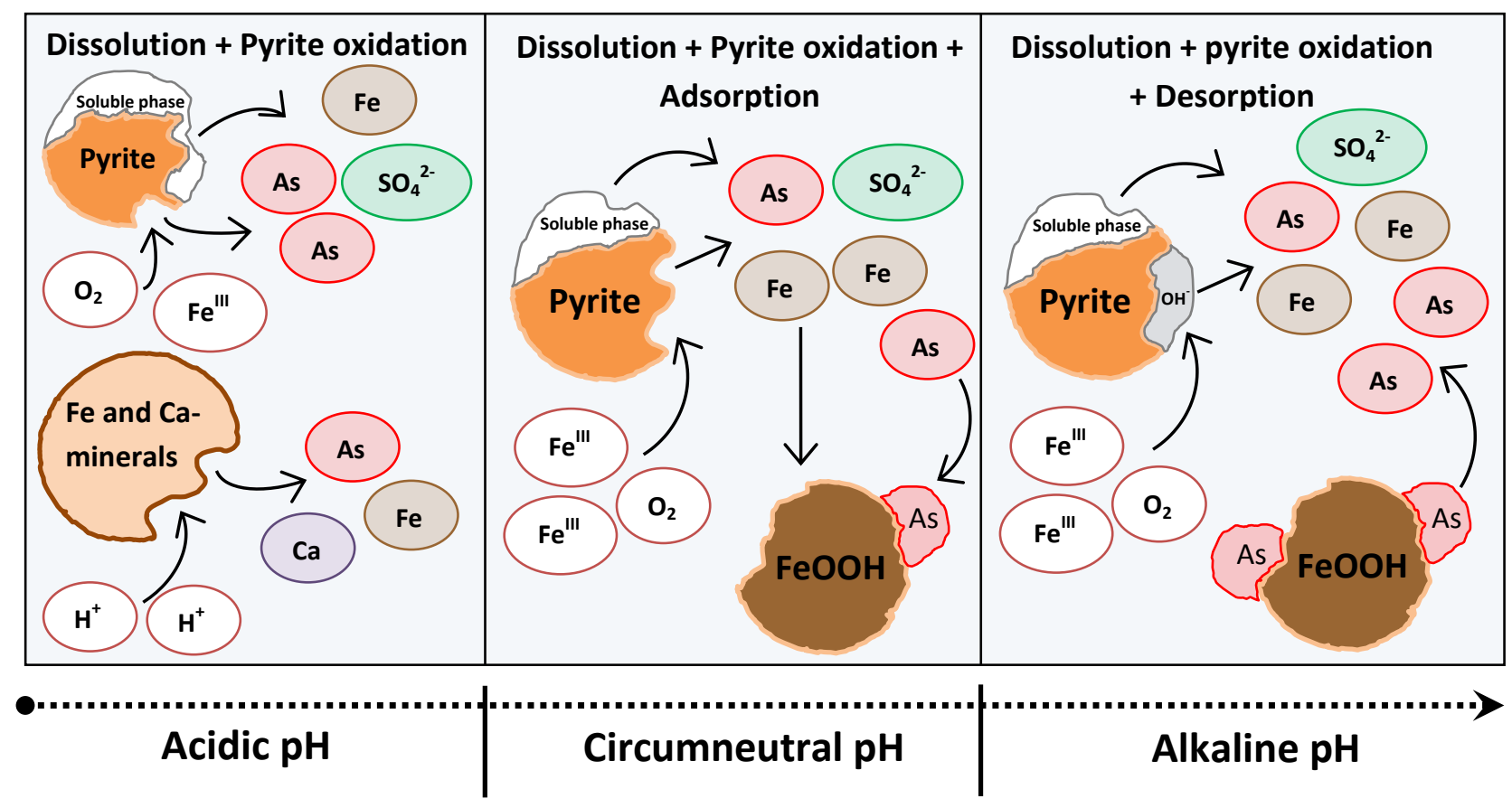

Figure 13

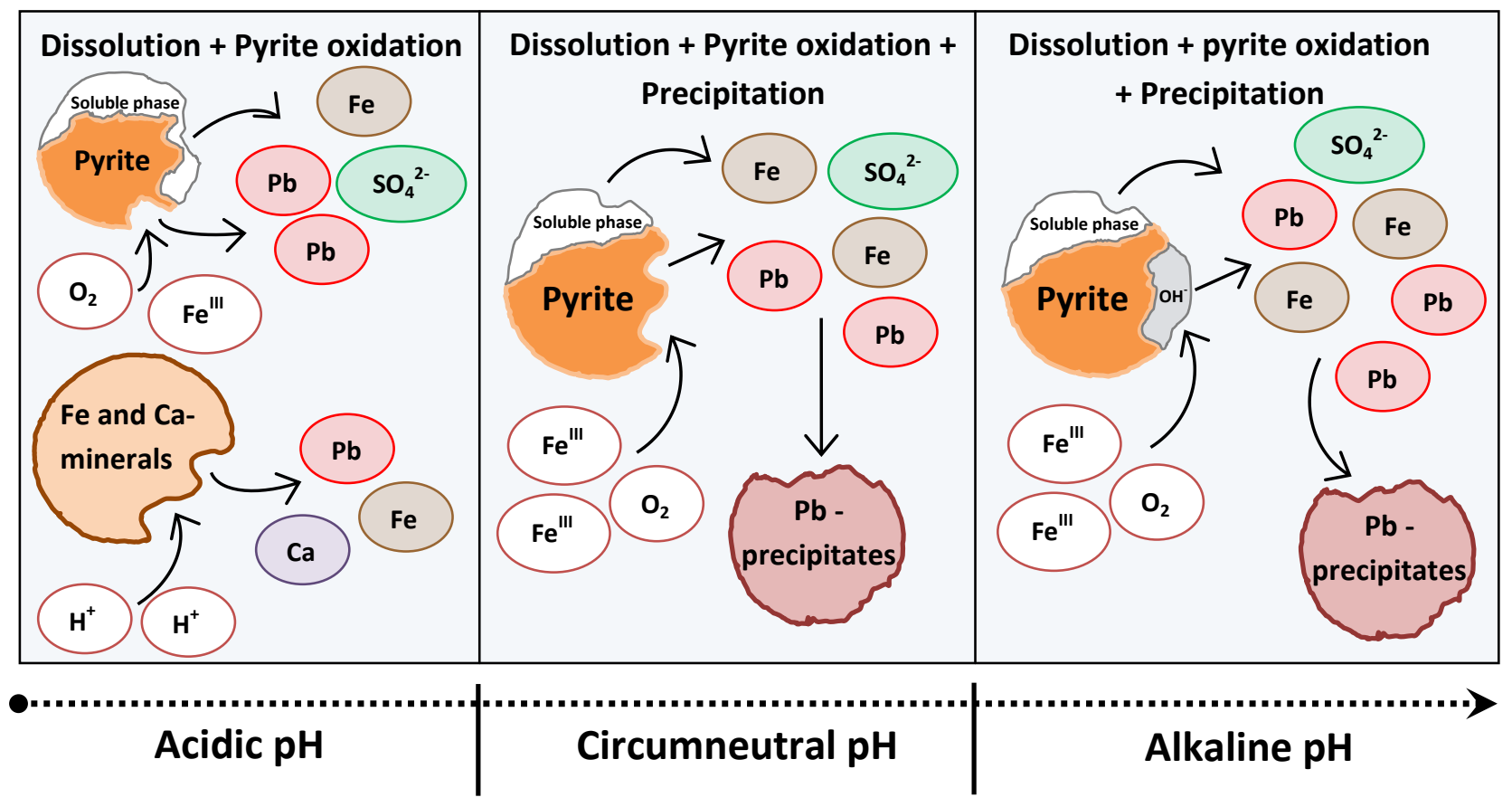

Figure 14 
Table 1. Brief description of the tunnel projects where the altered rock samples were collected.

\begin{tabular}{|c|c|c|c|c|}
\hline Sample & Type & Location & $\begin{array}{l}\text { Purpose of } \\
\text { excavation }\end{array}$ & Brief geological summary \\
\hline VR 1 & Borehole core & Teine, Hokkaido & $\begin{array}{l}\text { Maintenance } \\
\text { tunnel }\end{array}$ & $\begin{array}{l}\text { Former mine with epithermal } \mathrm{Au}-\mathrm{Ag}- \\
\mathrm{Cu} \text { deposit }\end{array}$ \\
\hline VR 2 & Borehole core & Teine, Hokkaido & $\begin{array}{l}\text { Maintenance } \\
\text { tunnel }\end{array}$ & $\begin{array}{l}\text { Former mine with epithermal } \mathrm{Au}-\mathrm{Ag}- \\
\mathrm{Cu} \text { deposit }\end{array}$ \\
\hline VR 3 & Borehole core & Teine, Hokkaido & $\begin{array}{l}\text { Maintenance } \\
\text { tunnel }\end{array}$ & $\begin{array}{l}\text { Former mine with epithermal } \mathrm{Au}-\mathrm{Ag} \text { - } \\
\mathrm{Cu} \text { deposit }\end{array}$ \\
\hline VR 4 & $\begin{array}{l}\text { Bulk excavated } \\
\text { rock }\end{array}$ & Teine, Hokkaido & $\begin{array}{l}\text { Maintenance } \\
\text { tunnel }\end{array}$ & $\begin{array}{l}\text { Former mine with epithermal } \mathrm{Au}-\mathrm{Ag} \text { - } \\
\mathrm{Cu} \text { deposit }\end{array}$ \\
\hline SR 1 & $\begin{array}{l}\text { Bulk excavated } \\
\text { rock }\end{array}$ & $\begin{array}{l}\text { Kamikawa, } \\
\text { Hokkaido }\end{array}$ & Road & $\begin{array}{l}\text { Altered Mesozoic sedimentary rock } \\
\text { composed mainly of slate from the } \\
\text { Hidaka metamorphic belt }\end{array}$ \\
\hline SR 2 & Borehole core & $\begin{array}{l}\text { Kamikawa, } \\
\text { Hokkaido }\end{array}$ & Road & $\begin{array}{l}\text { Altered Mesozoic sedimentary rock } \\
\text { composed mainly of slate from the } \\
\text { Hidaka metamorphic belt }\end{array}$ \\
\hline SR 3 & $\begin{array}{l}\text { Bulk excavated } \\
\text { rock }\end{array}$ & $\begin{array}{l}\text { Obihiro, } \\
\text { Hokkaido }\end{array}$ & Road & $\begin{array}{l}\text { Partly altered mudstone/sandstone of } \\
\text { marine origin from the Cretaceous } \\
\text { period }\end{array}$ \\
\hline
\end{tabular}

Table 2. Chemical composition of rock samples used in the leaching experiments.

\begin{tabular}{ccccccccccccccc}
\hline Sample & $\begin{array}{c}\mathrm{SiO}_{2} \\
(\mathrm{wt} \%)\end{array}$ & $\begin{array}{c}\mathrm{Al}_{2} \mathrm{O}_{3} \\
(\mathrm{wt} \%)\end{array}$ & $\begin{array}{c}\mathrm{Fe}_{2} \mathrm{O}_{3} \\
(\mathrm{wt} \%)\end{array}$ & $\begin{array}{c}\mathrm{MnO} \\
(\mathrm{wt} \%)\end{array}$ & $\begin{array}{c}\mathrm{MgO} \\
(\mathrm{wt} \%)\end{array}$ & $\begin{array}{c}\mathrm{CaO} \\
(\mathrm{wt} \%)\end{array}$ & $\begin{array}{c}\mathrm{Na}_{2} \mathrm{O} \\
(\mathrm{wt} \%)\end{array}$ & $\begin{array}{c}\mathrm{K}_{2} \mathrm{O} \\
(\mathrm{wt} \%)\end{array}$ & $\begin{array}{c}\mathrm{TiO}_{2} \\
(\mathrm{wt} \%)\end{array}$ & $\begin{array}{c}\mathrm{P}_{2} \mathrm{O}_{5} \\
(\mathrm{wt} \%)\end{array}$ & $\begin{array}{c}\mathrm{S} \\
(\text { wt\% })\end{array}$ & $\begin{array}{c}\mathrm{LOI} \\
(\text { wt\% })\end{array}$ & $\begin{array}{c}\mathrm{Pb} \\
(\mathrm{ppm})\end{array}$ & $\begin{array}{c}\mathrm{As} \\
(\mathrm{ppm})\end{array}$ \\
\hline $\mathrm{VR} 1$ & 77.6 & 13.5 & 2.85 & 0.06 & 0.06 & 0.03 & 0.24 & 1.37 & 0.47 & 0.06 & 1.82 & 5.91 & 439 & 1480 \\
$\mathrm{VR} 2$ & 82.2 & 13.2 & 3.17 & 0.01 & 0.05 & 0.04 & 0.24 & 0.26 & 0.48 & 0.04 & 1.6 & 6.63 & 166 & 218 \\
$\mathrm{VR} 3$ & 80.7 & 17.2 & 3.75 & 0.01 & 0.06 & 0.01 & 0.26 & 1.57 & 0.28 & 0.05 & 2.61 & 4.23 & 1910 & 101 \\
$\mathrm{VR} 4$ & 63.3 & 6.88 & 16.0 & 0.02 & 0.05 & 0.05 & 0.01 & 0.10 & 0.25 & 0.06 & 10.6 & 12.7 & 375 & 150 \\
$\mathrm{SR} 1$ & 58.7 & 14.4 & 6.22 & 0.07 & 3.49 & 3.31 & 1.31 & 3.22 & 0.82 & 0.13 & 0.2 & 6.26 & $\mathrm{BDL}$ & 23.6 \\
$\mathrm{SR} 2$ & 63 & 12.1 & 5.43 & 0.1 & 2.85 & 1.59 & 0.5 & 3.02 & 0.41 & 0.04 & 0.27 & 2.86 & $\mathrm{BDL}$ & 10.5 \\
$\mathrm{SR} 3$ & 65.8 & 15 & 6.4 & 0.07 & 2.81 & 2.6 & 1.7 & 3.54 & 0.72 & 0.17 & 0.48 & 6.77 & $\mathrm{BDL}$ & 6.9 \\
\hline
\end{tabular}

Table 3: Mineralogical composition of rock samples determined using XRD.

\begin{tabular}{cccccccccc}
\hline Sample & Qz & Pl & Chl & Cal & Py & Kao & Gal & Bir & Mus \\
\hline VR1 & +++ & & & & + & - & & & \\
VR2 & +++ & & & & + & - & & & \\
VR3 & +++ & & & & + & - & - & & \\
VR4 & +++ & & & & + & - & - & - & \\
SR1 & +++ & ++ & - & + & - & - & & & - \\
SR2 & +++ & ++ & & + & - & - & & & - \\
SR3 & +++ & ++ & + & + & - & & & & \\
\hline
\end{tabular}

+++: Major; ++: Moderate; +: Minor; -: Trace

Qz: Quartz; Pl: Plagioclase; Chl: Chlorite; Cal: Calcite; Py: Pyrite; Kao: Kaolinite; Gal:

Galena; Bir: Birnessite; Mus: Muscovite

*Note: In samples with little or no volcanic glass (e.g., sedimentary rocks), major, moderate, minor and trace roughly represent $>30 \%, 10-30 \%, 2-10 \%$ and $<2 \%$, respectively. 
Table 4. EPMA data of As and $\mathrm{Pb}$ from minerals inside and outside the fractured area of the sedimentary rock (SR3).

\begin{tabular}{ccccccc}
\hline \multicolumn{7}{c}{ Inside the fractured zone } \\
\hline Mineral name & No. & $\mathrm{S}(\mathrm{wt} \%)$ & Fe (wt\%) & As (wt\%) & $\begin{array}{c}\mathrm{Pb} \\
(\mathrm{wt} \%)\end{array}$ & Total \\
\hline Pyrite & 1 & 49.8 & 46.2 & 0.13 & $<0.01$ & 96.1 \\
& 2 & 49.5 & 45.3 & 0.11 & $<0.01$ & 94.9 \\
\multirow{2}{*}{ Smectite } & 3 & 50.5 & 43.3 & 0.06 & $<0.01$ & 93.9 \\
& 1 & 0.01 & 3.42 & $<0.01$ & 0.04 & 3.47 \\
Illite & 2 & 0.01 & 4.63 & $<0.01$ & $<0.01$ & 4.64 \\
& 1 & 0.01 & 3.25 & 0.07 & 0.03 & 3.29 \\
\hline \multirow{2}{*}{ Mineral name } & No. & $\mathrm{S}(\mathrm{wt} \%)$ & Fe (wt\%) & As (wt $\%)$ & $\mathrm{Pb}$ & Total \\
& 1 & 50.9 & 46.7 & $<0.01$ & $<0.01$ & 97.6 \\
Pyrite & 2 & 51 & 46.1 & $<0.01$ & $<0.01$ & 97.1 \\
& 3 & 51.2 & 45.7 & $<0.01$ & $<0.01$ & 96.9 \\
Calcite & 1 & 0.06 & 0.22 & $<0.01$ & 0.03 & 0.31 \\
\hline
\end{tabular}

Table 5. EPMA data of $\mathrm{Fe}, \mathrm{S}, \mathrm{As}$ and $\mathrm{Pb}$ in pyrite from altered volcanic rocks (VR1, 2 and 3).

\begin{tabular}{cccccccccc}
\hline No. & $\begin{array}{c}\mathrm{S} \\
(\mathrm{wt} \%)\end{array}$ & $\begin{array}{c}\mathrm{S} \\
(\mathrm{at} \%)\end{array}$ & $\begin{array}{c}\mathrm{Fe} \\
(\mathrm{wt} \%)\end{array}$ & $\begin{array}{c}\mathrm{Fe} \\
(\mathrm{at} \%)\end{array}$ & $\begin{array}{c}\mathrm{As} \\
(\mathrm{wt} \%)\end{array}$ & $\begin{array}{c}\mathrm{As} \\
(\mathrm{at} \%)\end{array}$ & $\begin{array}{c}\mathrm{Pb} \\
(\mathrm{wt} \%)\end{array}$ & $\begin{array}{c}\mathrm{Pb} \\
(\mathrm{at} \%)\end{array}$ & Total \\
\hline 1 & 54.2 & 67.1 & 45.9 & 32.6 & 0.55 & 0.28 & 0.26 & 0.04 & 100.9 \\
2 & 53.4 & 66.7 & 46.3 & 33.1 & 0.38 & 0.20 & 0.07 & 0.01 & 100.1 \\
3 & 53.6 & 67.0 & 46 & 32.9 & 0.14 & 0.08 & 0.18 & 0.04 & 99.9 \\
4 & 52.9 & 66.1 & 46.3 & 33.3 & 1.07 & 0.56 & 0.08 & 0.02 & 100.3 \\
5 & 53.7 & 66.8 & 46.6 & 33.2 & 0.09 & 0.04 & 0.11 & 0.02 & 100.5 \\
6 & 54 & 66.9 & 46.5 & 33.1 & $<0.01$ & $<0.01$ & 0.15 & 0.03 & 100.6 \\
7 & 53.7 & 66.5 & 46.7 & 33.5 & $<0.01$ & $<0.01$ & 0.07 & 0.01 & 100.5 \\
8 & 52.7 & 66.6 & 45.2 & 32.9 & 0.97 & 0.53 & 0.19 & 0.04 & 99.1 \\
9 & 54 & 66.9 & 46.6 & 33.1 & 0.01 & 0.01 & 0.19 & 0.04 & 100.8 \\
10 & 54.2 & 66.8 & 46.9 & 33.2 & 0.02 & 0.01 & 0.09 & 0.02 & 101.2 \\
11 & 54.1 & 66.8 & 47.1 & 33.2 & 0.02 & 0.01 & 0.09 & 0.02 & 101.3 \\
12 & 53.9 & 66.3 & 47.2 & 33.5 & 0.19 & 0.12 & 0.15 & 0.03 & 101.4 \\
13 & 52.4 & 67.1 & 44.4 & 32.7 & 0.35 & 0.19 & $<0.01$ & $<0.01$ & 97.15 \\
14 & 51.4 & 66.2 & 45.6 & 33.7 & 0.03 & 0.02 & 0.12 & 0.02 & 97.15 \\
15 & 54.2 & 66.4 & 47.8 & 33.6 & 0.01 & 0.01 & 0.11 & 0.02 & 102.1 \\
16 & 54.3 & 66.3 & 47.9 & 33.6 & 0.12 & 0.06 & 0.09 & 0.02 & 102.4 \\
Minimum & 51.4 & 66.1 & 44.4 & 32.6 & $<0.01$ & $<0.01$ & $<0.01$ & $<0.01$ & 99.1 \\
Maximum & 54.3 & 67.1 & 47.9 & 33.7 & 1.07 & 0.56 & 0.26 & 0.04 & 101.4 \\
Mean & 53.5 & 66.7 & 46.4 & 33.2 & 0.28 & 0.15 & 0.13 & 0.02 & 100.4 \\
\hline
\end{tabular}


Table 6. Leachate chemistry of sample SR1without $\mathrm{pH}$ adjustment in triplicate runs

\begin{tabular}{cccccc}
\hline Trial & $\mathrm{pH}$ & $\begin{array}{c}\mathrm{As} \\
(\mu \mathrm{g} / \mathrm{L})\end{array}$ & $\begin{array}{c}\mathrm{Fe} \\
(\mathrm{mg} / \mathrm{L})\end{array}$ & $\begin{array}{c}\mathrm{Ca}^{2+} \\
(\mathrm{mg} / \mathrm{L})\end{array}$ & $\begin{array}{c}\mathrm{SO}_{4}{ }^{2-} \\
(\mathrm{mg} / \mathrm{L})\end{array}$ \\
\hline 1 & 8.79 & 28.3 & 0.304 & 22.9 & 77.9 \\
2 & 8.79 & 35 & 0.307 & 23.4 & 77.8 \\
3 & 8.82 & 30.6 & 0.313 & 22.9 & 78.6 \\
$\begin{array}{c}\text { Mean } \\
\text { Standard } \\
\text { deviation }\end{array}$ & 8.8 & 31.3 & 0.308 & 23.1 & 78.1 \\
\hline
\end{tabular}

Table 7. Leachate chemistry of sample VR4 without $\mathrm{pH}$ adjustment in triplicate runs

\begin{tabular}{cccccc}
\hline Trial & $\mathrm{pH}$ & $\begin{array}{c}\mathrm{As} \\
(\mu \mathrm{g} / \mathrm{L})\end{array}$ & $\begin{array}{c}\mathrm{Fe} \\
(\mathrm{mg} / \mathrm{L})\end{array}$ & $\begin{array}{c}\mathrm{Ca}^{2+} \\
(\mathrm{mg} / \mathrm{L})\end{array}$ & $\begin{array}{c}\mathrm{SO}_{4}{ }^{2-} \\
(\mathrm{mg} / \mathrm{L})\end{array}$ \\
\hline 1 & 2.85 & 45.4 & 474 & 2.1 & 853 \\
2 & 2.82 & 47.9 & 471 & 3 & 843 \\
3 & 2.83 & 44.5 & 476 & 1.8 & 853 \\
$\begin{array}{c}\text { Mean } \\
\text { Standard } \\
\text { deviation }\end{array}$ & 0.015 & 45.9 & 473 & 2.3 & 850 \\
\hline
\end{tabular}

Table 8. Leachate chemistry of the altered rocks without $\mathrm{pH}$ adjustment under oxic conditions.

\begin{tabular}{|c|c|c|c|c|c|c|}
\hline Sample & $\mathrm{pH}$ & $\begin{array}{c}\text { As } \\
(\mu \mathrm{g} / \mathrm{L})\end{array}$ & $\begin{array}{c}\mathrm{Pb} \\
(\mathrm{mg} / \mathrm{L})\end{array}$ & $\begin{array}{c}\mathrm{Fe} \\
(\mathrm{mg} / \mathrm{L})\end{array}$ & $\begin{array}{c}\mathrm{Ca}^{2+} \\
(\mathrm{mg} / \mathrm{L})\end{array}$ & $\begin{array}{c}\mathrm{SO}_{4}{ }^{2-} \\
(\mathrm{mg} / \mathrm{L})\end{array}$ \\
\hline VR1 & 3.86 & 195 & 1.48 & 16.2 & 2.62 & 100 \\
\hline VR2 & 3.39 & 102 & 0.353 & 33.3 & 3.03 & 144 \\
\hline VR3 & 3.99 & 94.7 & 0.773 & 8.59 & 2.4 & 67.8 \\
\hline VR4 & 2.85 & 45.4 & 2.12 & 474 & 2.1 & 853 \\
\hline SR1 & 8.79 & 28.3 & - & 0.304 & 22.9 & 77.9 \\
\hline SR2 & 8.49 & 46.8 & - & 0.113 & 17.3 & 12.7 \\
\hline SR3 & 10.32 & 17.25 & - & 0.648 & 5.18 & 58.9 \\
\hline
\end{tabular}


Table 9. Leachate chemistry of sample VR2 under oxic, anoxic and mixed $\mathrm{CO}_{2} / \mathrm{Ar}$ gases.

\begin{tabular}{ccccccc}
\hline Conditions & $\mathrm{pH}$ & $\begin{array}{c}\mathrm{As} \\
(\mu \mathrm{g} / \mathrm{L})\end{array}$ & $\begin{array}{c}\mathrm{Pb} \\
(\mathrm{mg} / \mathrm{L})\end{array}$ & $\begin{array}{c}\mathrm{Fe} \\
(\mathrm{mg} / \mathrm{L})\end{array}$ & $\begin{array}{c}\mathrm{Ca}^{2+} \\
(\mathrm{mg} / \mathrm{L})\end{array}$ & $\begin{array}{c}\mathrm{SO}_{4}{ }^{2-} \\
(\mathrm{mg} / \mathrm{L})\end{array}$ \\
\hline Anoxic & 3.45 & 12.9 & 0.374 & 25.9 & 0.284 & 121 \\
Oxic & 3.39 & 102 & 0.353 & 33.3 & 3.03 & 144 \\
$1 \% \mathrm{CO}_{2} ; 99 \%$ Ar gas & 3.4 & 12.5 & 0.382 & 25.3 & 0.831 & 124 \\
$3 \% \mathrm{CO}_{2} ; 97 \%$ Ar gas & 3.48 & 12.7 & 0.375 & 24.8 & 0.646 & 134 \\
\hline
\end{tabular}

Table 10. Leachate chemistry of sample SR2 under oxic, anoxic and mixed $\mathrm{CO}_{2} /$ Ar gases.

\begin{tabular}{cccccc}
\hline Conditions & $\mathrm{pH}$ & $\begin{array}{c}\mathrm{As} \\
(\mu \mathrm{g} / \mathrm{L})\end{array}$ & $\begin{array}{c}\mathrm{Fe} \\
(\mathrm{mg} / \mathrm{L})\end{array}$ & $\begin{array}{c}\mathrm{Ca}^{2+} \\
(\mathrm{mg} / \mathrm{L})\end{array}$ & $\begin{array}{c}\mathrm{SO}_{4}{ }^{2-} \\
(\mathrm{mg} / \mathrm{L})\end{array}$ \\
\hline Anoxic & 9.21 & 14.8 & 0.101 & 9.44 & 11.7 \\
Oxic & 8.49 & 46.8 & 0.113 & 17.3 & 12.7 \\
$1 \% \mathrm{CO}_{2} ; 99 \%$ Ar gas & 7.29 & 3.8 & 0.028 & 33.7 & 15 \\
$3 \% \mathrm{CO}_{2} ; 97 \%$ Ar gas & 6.90 & 3.8 & 0.021 & 55.5 & 12.3 \\
$30 \% \mathrm{CO}_{2} ; 70 \%$ Ar gas & 6.10 & 3.35 & 0.012 & 108 & 12.7 \\
\hline
\end{tabular}

Table 11. Calculated saturation indices for sample VR 1

\begin{tabular}{lcccc}
\hline & \multicolumn{4}{c}{ Leachate } \\
& 1 & 2 & 3 & 4 \\
\hline Parameter & 3.86 & 4.34 & 7.75 & 9.95 \\
pH (measured) & 9.06 & 8.65 & 6.15 & 6.15 \\
pe (calculated from Eh) & & & & \\
Saturation indices & & & & \\
Gypsum $\left(\mathrm{CaSO}_{4} \cdot 2 \mathrm{H}_{2} \mathrm{O}\right)$ & -2.51 & -2.62 & -4.38 & -5.60 \\
Calcite $\left(\mathrm{CaCO}_{3}\right)$ & - & - & -3.81 & -2.75 \\
Anglesite $\left(\mathrm{PbSO}_{4}\right)$ & -0.39 & -0.70 & -2.96 & -4.74 \\
Cerrusite $\left(\mathrm{PbCO}_{3}\right)$ & - & - & -0.62 & -0.12 \\
Hydrocerrusite $\left(\mathrm{Pb}\left(\mathrm{CO}_{3}\right)_{2}(\mathrm{OH})_{2}\right)$ & - & - & -2.19 & 1.35 \\
$\mathrm{~Pb}(\mathrm{OH})_{2}$ & -6.0 & -5.33 & -0.91 & 1.62 \\
$\mathrm{Fe}(\mathrm{OH})_{3}$ & -0.05 & 0.53 & 3.46 & 3.15 \\
$\mathrm{Goethite}(\mathrm{FeOOH})$ & 4.12 & 4.70 & 7.63 & 7.32 \\
Hematite, alpha $\left(\mathrm{Fe}_{2} \mathrm{O}_{3}\right)$ & 7.75 & 8.90 & 14.8 & 14.4 \\
Magnetite, alpha $\left(\mathrm{Fe}_{3} \mathrm{O}_{4}\right)$ & 1.48 & 3.14 & 11.0 & 7.89 \\
\hline
\end{tabular}


Table 12. Calculated saturation indices for sample SR 1

\begin{tabular}{lccccc}
\hline & 1 & 2 & 3 & 4 & 5 \\
\hline Parameter & & & & & \\
pH (measured) & 1.95 & 4.38 & 7.64 & 8.21 & 11.8 \\
pe (calculated from Eh) & 10.7 & 8.07 & 5.54 & 5.63 & 3.03 \\
& & & & & \\
Saturation indices & & & & & \\
Gypsum $\left(\mathrm{CaSO}_{4} \cdot 2 \mathrm{H}_{2} \mathrm{O}\right)$ & -0.57 & -0.67 & -0.81 & -0.98 & -3.1 \\
$\mathrm{Calcite}\left(\mathrm{CaCO}_{3}\right)$ & - & - & -0.12 & 0.94 & 1.29 \\
$\mathrm{Fe}(\mathrm{OH})_{3}$ & -3.22 & 0.52 & 2.12 & 2.09 & 0.71 \\
$\mathrm{Goethite}(\mathrm{FeOOH})$ & 0.94 & 4.68 & 6.29 & 6.25 & 4.88 \\
Hematite, alpha $\left(\mathrm{Fe}_{2} \mathrm{O}_{3}\right)$ & 1.39 & 8.87 & 12.1 & 12 & 9.29 \\
Magnetite, alpha $\left(\mathrm{Fe}_{3} \mathrm{O}_{4}\right)$ & -7.8 & 3.64 & 7.73 & 5.77 & 1.84 \\
\hline
\end{tabular}

Table 13. Chemical reactions and equilibrium constants at $25^{\circ} \mathrm{C}$ of hematite, magnetite and goethite in the presence of $\mathrm{O}_{2}$ and $\mathrm{N}_{2}$ using Geochemist's workbench ${ }^{\circledR} \mathrm{RXN}$ program.

\begin{tabular}{ll}
\hline Chemical reactions & $\log K$ \\
\hline $2 \mathrm{Fe}^{2+}{ }_{(\mathrm{aq})}+2 \mathrm{H}_{2} \mathrm{O}+0.5 \mathrm{O}_{2(\mathrm{aq})} \longleftrightarrow$ Hematite $\left(\mathrm{Fe}_{2} \mathrm{O}_{3}\right)_{(\mathrm{s})}+4 \mathrm{H}^{+}$ & 16.9 \\
$3 \mathrm{Fe}^{2+}{ }_{(\mathrm{aq})}+3 \mathrm{H}_{2} \mathrm{O}+0.5 \mathrm{O}_{2(\mathrm{aq})} \longleftrightarrow$ Magnetite $\left(\mathrm{Fe}_{3} \mathrm{O}_{4}\right)_{(\mathrm{s})}+6 \mathrm{H}^{+}$ & 6.68 \\
$\mathrm{Fe}^{2+}{ }_{(\mathrm{aq})}+1.5 \mathrm{H}_{2} \mathrm{O}+0.25 \mathrm{O}_{2(\mathrm{aq})} \longleftrightarrow$ Goethite $(\mathrm{FeOOH})_{(\mathrm{s})}+2 \mathrm{H}^{+}$ & 7.99 \\
$2 \mathrm{Fe}^{2+}{ }_{(\mathrm{aq})}+1.8 \mathrm{H}_{2} \mathrm{O}+0.4 \mathrm{NO}_{3(\mathrm{aq})}^{-} \longleftrightarrow$ Hematite $\left(\mathrm{Fe}_{2} \mathrm{O}_{3}\right)_{(\mathrm{s})}+3.6 \mathrm{H}^{+}+0.2 \mathrm{~N}_{2(\mathrm{aq})}$ & 15.4 \\
$3 \mathrm{Fe}^{2+}{ }_{(\mathrm{aq})}+2.8 \mathrm{H}_{2} \mathrm{O}+0.4 \mathrm{NO}_{3(\mathrm{aq})}^{-} \longleftrightarrow$ Magnetite $\left(\mathrm{Fe}_{3} \mathrm{O}_{4}\right)_{(\mathrm{s})}+5.6 \mathrm{H}^{+}+0.2 \mathrm{~N}_{2(\mathrm{aq})}$ & 5.13 \\
$\mathrm{Fe}^{2+}{ }_{\text {(aq) }}+1.4 \mathrm{H}_{2} \mathrm{O}+0.2 \mathrm{NO}_{3(\mathrm{aq})}^{-} \longleftrightarrow$ Goethite $(\mathrm{FeOOH})_{(\mathrm{s})}+1.8 \mathrm{H}^{+}+0.1 \mathrm{~N}_{2(\mathrm{aq})}$ & 7.21 \\
\hline
\end{tabular}

Table 14. $\mathrm{pH}$ and concentrations of $\mathrm{Ca}^{2+}, \mathrm{Fe}$ and $\mathrm{SO}_{4}{ }^{2-}$ in simulated systems under equilibrium conditions, and measured values from sample SR1

\begin{tabular}{cccccc}
\hline Type of system & $\begin{array}{c}\text { Ratio of } \\
\text { minerals (mol) }\end{array}$ & $\mathrm{pH}$ & $\begin{array}{c}\mathrm{Ca}^{2+} \\
(\mathrm{mol} / \mathrm{L})\end{array}$ & $\begin{array}{c}\mathrm{Fe} \\
(\mathrm{mol} / \mathrm{L})\end{array}$ & $\begin{array}{c}\mathrm{SO}_{4}{ }^{2-} \\
(\mathrm{mol} / \mathrm{L})\end{array}$ \\
\hline $\begin{array}{c}\text { altered sedimentary } \\
\text { rock (SR1) }\end{array}$ & - & 8.79 & $5.7 \times 10^{-4}$ & $5.4 \times 10^{-6}$ & $8.1 \times 10^{-4}$ \\
$\begin{array}{c}\text { calcite only } \\
\text { calcite : pyrite }\end{array}$ & $10: 1$ & 9.23 & $2.3 \times 10^{-4}$ & $4.1 \times 10^{-5}$ & $1.5 \times 10^{-4}$ \\
$\begin{array}{c}\text { calcite }: \text { pyrite : } \\
\text { gypsum }\end{array}$ & $10: 1: 4.2 \times$ & 8.91 & $5.8 \times 10^{-4}$ & $5.3 \times 10^{-5}$ & $5.3 \times 10^{-4}$ \\
$\begin{array}{c}\text { calcite : pyrite : } \\
\text { gypsum : melanterite }\end{array}$ & $100^{-4}: 1: 4.2 \times$ & & & & \\
\hline
\end{tabular}


Table 15. $\mathrm{pH}$ and concentrations of $\mathrm{Ca}^{2+}, \mathrm{Fe}$ and $\mathrm{SO}_{4}{ }^{2-}$ in simulated systems under equilibrium conditions, and measured values from sample VR4

\begin{tabular}{cccccc}
\hline Type of system & $\begin{array}{c}\text { Ratio of } \\
\text { minerals (mol) }\end{array}$ & $\mathrm{pH}$ & $\begin{array}{c}\mathrm{Ca}^{2+} \\
(\mathrm{mol} / \mathrm{L})\end{array}$ & $\begin{array}{c}\mathrm{Fe} \\
(\mathrm{mol} / \mathrm{L})\end{array}$ & $\begin{array}{c}\mathrm{SO}_{4}^{2-} \\
(\mathrm{mol} / \mathrm{L})\end{array}$ \\
\hline $\begin{array}{c}\text { altered volcanic } \\
\text { rock (VR4) }\end{array}$ & - & 2.85 & $5.7 \times 10^{-5}$ & $8.5 \times 10^{-3}$ & $9.0 \times 10^{-3}$ \\
pyrite only & 10 & 3.83 & - & $7.4 \times 10^{-5}$ & $1.5 \times 10^{-4}$ \\
pyrite : gypsum & $10: 6 \times 10^{-5}$ & 3.84 & $5.8 \times 10^{-5}$ & $7.4 \times 10^{-5}$ & $2.1 \times 10^{-5}$ \\
$\begin{array}{c}\text { pyrite : gypsum : } \\
\text { melanterite }\end{array}$ & $\begin{array}{c}10: 6 \times 10^{-5}: \\
1.25 \times 10^{-2}\end{array}$ & 4.05 & $4.1 \times 10^{-5}$ & $9.0 \times 10^{-3}$ & $9.0 \times 10^{-3}$ \\
\hline
\end{tabular}

Table 16. Simulated $\mathrm{pH}$ concentrations of $\mathrm{Ca}^{2+}$ and $\mathrm{SO}_{4}{ }^{2-}$ in a calcite-pyrite-gypsummelanterite system under equilibrium conditions, and measured values from sample SR1

\begin{tabular}{ccccc}
\hline Parameters & \multicolumn{3}{c}{$\begin{array}{c}\text { Simulated } \\
\text { Anoxic - oxic }\end{array}$} & $\begin{array}{c}\text { Measured } \\
\text { Anoxic - oxic }\end{array}$ \\
\hline$P_{O 2}$ & $10^{-34}$ & $10^{-1.36}$ & $10^{-0.68}$ & - \\
$P_{C O 2}$ & $10^{-175}$ & $10^{-7.0}$ & $10^{-3.5}$ & - \\
$\mathrm{pH}$ & 9.23 & 9.15 & 8.83 & $9.01-8.79$ \\
$\mathrm{Ca}^{2+}(\mathrm{mol} / \mathrm{L})$ & $5.2 \times 10^{-4}$ & $5.4 \times 10^{-4}$ & $6.3 \times 10^{-4}$ & $4.6 \times 10^{-4}-5.7 \times 10^{-4}$ \\
$\mathrm{SO}_{4}{ }^{2-}(\mathrm{mol} / \mathrm{L})$ & $6.8 \times 10^{-4}$ & $7.1 \times 10^{-4}$ & $8.1 \times 10^{-4}$ & $7.1 \times 10^{-4}-8.1 \times 10^{-4}$ \\
\hline
\end{tabular}

Table 17. Simulated $\mathrm{pH}$ and concentrations of $\mathrm{Ca}^{2+}$ and $\mathrm{SO}_{4}{ }^{2-}$ in a pyrite-gypsummelanterite system under equilibrium conditions, and measured values from sample VR4

\begin{tabular}{ccccc}
\hline Parameters & \multicolumn{3}{c}{$\begin{array}{c}\text { Simulated } \\
\text { Anoxic - oxic }\end{array}$} & $\begin{array}{c}\text { Measured } \\
\text { Anoxic - oxic }\end{array}$ \\
\hline$P_{O 2}$ & $10^{-34}$ & $10^{-1.36}$ & $10^{-0.68}$ & - \\
$P_{C O 2}$ & $10^{-175}$ & $10^{-7.0}$ & $10^{-3.5}$ & - \\
$\mathrm{pH}$ & 6 & 4.7 & 4.05 & $3.03-2.85$ \\
$\mathrm{Ca}^{2+}(\mathrm{mol} / \mathrm{L})$ & $4.1 \times 10^{-5}$ & $4.1 \times 10^{-5}$ & $4.1 \times 10^{-5}$ & $5.7 \times 10^{-5}-5.2 \times 10^{-4}$ \\
$\mathrm{SO}_{4}{ }^{2-}(\mathrm{mol} / \mathrm{L})$ & $9.0 \times 10^{-2}$ & $9.0 \times 10^{-3}$ & $9.0 \times 10^{-3}$ & $9.0 \times 10^{-3}-9.0 \times 10^{-3}$ \\
\hline
\end{tabular}

